\title{
19. LATE CENOZOIC PLANKTONIC FORAMINIFERA AND PALEOCEANOGRAPHY AT DSDP SITE 284 IN THE COOL SUBTROPICAL SOUTH PACIFIC
}

\author{
James P. Kennett, Graduate School of Oceanography, University of Rhode Island, Kingston, Rhode Island \\ and \\ Paul Vella, Geology Department, Victoria University of Wellington, Wellington, New Zealand
}

\begin{abstract}
Population statistics of planktonic foraminiferal samples through DSDP Site 284 (late Miocene to Recent) indicate surface-water temperature variations. According to biostratigraphic correlations, the temperature variations were less intense than, but were synchronous with inferred temperature variations on the eastern side of the North Island of New Zealand. The biostratigraphy permitted dating by reference to the paleomagnetic sequences determined in New Zealand marine strata. Water temperatures were relatively warm until $t=4.7 \mathrm{~m} . \mathrm{y}$. and were significantly cooler between $t=4.7$ to $t=4.3$ m.y. (equivalent to Kapitean Stage of New Zealand). A brief minor warming is associated with the New Zealand MiocenePliocene boundary and is followed by a cool interval to $t=4.1 \mathrm{~m} . \mathrm{y}$. a prolonged warm interval to $t=2.6 \mathrm{~m}$.y. (Opoitian Stage), and a significantly cooler episode to $t=2.15 \mathrm{~m} . \mathrm{y}$. Following this, temperatures fluctuate to an early to mid Pleistocene disconformity.

The faunally determined paleotemperature changes coincide with changes in oxygen isotope composition of the water considered by Shackleton and Kennett (this volume) to indicate significant changes in ice volumes on Antarctica in the late Miocene and within the Northern Hemisphere in the late Pliocene and Pleistocene.

The validity of planktonic foraminiferal paleotemperatures, placed in doubt by contradictory molluscan data in California and New Zealand, is justified by the comparative simplicity of planktonic ecologies, consistent sympathetic variations of different parameters of planktonic foraminiferal populations, and their consistent relationship to oxygen isotope data and paleoglacial history.

Coiling of Neogloboquadrina pachyderma did not adopt its presentday pattern until early in the Pliocene and cannot be used for paleotemperature analysis of the late Miocene and early Pliocene faunas.
\end{abstract}

\section{INTRODUCTION}

Site 284 is situated near the edge of Challenger Plateau west of Wellington, New Zealand, at $40^{\circ} 30^{\prime} \mathrm{S}$ $167^{\circ} 41^{\prime} \mathrm{E}$ (Figure 1). Two holes were drilled, 284 was continuously cored to a depth of 208 meters and $284 \mathrm{~A}$ to obtain three 9 meter sections lost in 284 . The site was selected in relatively shallow water $(1068 \mathrm{~m})$ in order to obtain a late Cenozoic calcareous biogenic sequence. The sediments are nearly uniform nannofossilforaminiferal ooze and foraminiferal-nannofossil ooze, with virtually no terrigenous component. Preservation of the nannofossils and foraminifera indicate only slight solution.

The site provides a biostratigraphic and paleoclimatic record for the last 6 million years (except for a disconformity in the middle Pleistocene) in the Tasman Sea at the latitude of central New Zealand. The present environment is cool subtropical (temperate) with the subtropical convergence zone $400 \mathrm{~km}$ to the south. It is a useful site for linking the biostratigraphy at Site 207
(DSDP Leg 21) with that of New Zealand marine sediments on land and also for verification of paleoclimatic studies that have been carried out in New Zealand. It is especially significant for New Zealand because it provides a sequence that unequivocally is not modified by reduced salinities or shallowness, contains abundant planktonic foraminifera and calcareous nannofossils, and is virtually continuous.

Planktonic foraminiferal biostratigraphy and population statistics are presented in this paper, while oxygen isotope analyses of samples of the benthonic foraminiferal genus Uvigerina are presented in a separate paper by Shackleton and Kennett (Chapter 20, this volume).

\section{BIOSTRATIGRAPHY}

Site 284 is only $3^{\circ}$ of latitude south of Site 207, but the water differences have been sufficiently marked that the biostratigraphy is not identical. The lowest occurrence of Globorotalia crassaformis nearly coincides with that of $G$. puncticulata and does not distinguish a separate $G$. 


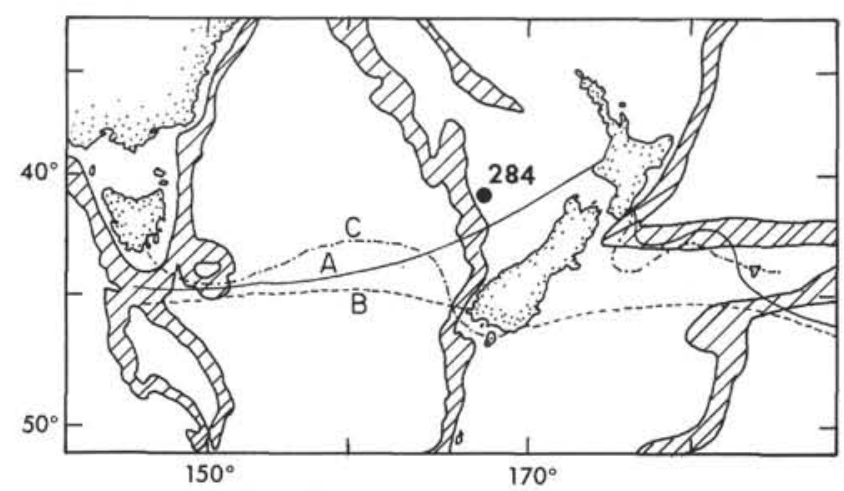

Figure 1. Location of DSDP Site 284 on the Challenger Plateau showing (a) the trend of the subtropical convergence according to Deacon (1937); (b) the southern limit of a zone of mixed waters which Fleming (1944) described between subantarctic and subtropical water; and $(c)$ the general form of the subtropical convergence after Garner (1954).

crassaformis Zone as at Site 207. Globorotalia tosaensis is not represented in the late Pliocene and early Pleistocene. Five clearly defined biostratigraphic units are recognized and are correlated with the zones at Site 207 and with the New Zealand stages (Table 1).

The important biostratigraphic datum surfaces used for this correlation are:

1) lowest occurrence of Globorotalia truncatulinoides (d'Orbigny)-base of informal Zone 1, base of Hautawan Stage, approximate New Zealand PlioceneQuaternary boundary;
2) lowest occurrence of Globorotalia inflata (d'Orbigny)-base of informal Zone 2, within upper Opoitian Stage;

3) lowest occurrence of Globorotalia puncticulata (Deshayes) - base of informal Zone 3, base of Opoitian Stage, New Zealand Miocene-Pliocene boundary;

4) lowest occurrence of Globorotalia conomiozea Kennett-base of informal Zone 4 , base of Kapitean Stage.

\section{CHRONOLOGY}

The surfaces defined by the lowest occurrences of $G$. conomiozea and $G$. puncticulata are paleomagnetically dated inn New Zealand at $t=4.7$ and $t=4.3 \mathrm{~m} . \mathrm{y}$., respectively (Kennett and Watkins, in press). The age of the surface defined by the lowest occurrences of $G$. truncatulinoides is taken to be 1.8 m.y. (Berggren et al., 1967; Phillips et al., 1968). The first major cooling in the late Pliocene at Site 284 is assumed to be the same age as the Waipipian cooling in New Zealand (Devereux et al., 1970; Kennett et al., 1971) with a cooling maximum at about $t=2.4$ m.y. A second significant cooling at Site 284 indicated about 15-18 meters above the base of the Quaternary is presumed to correspond to a New Zealand cooling within the Gilsa Event (Vella and Nicol, 1972).

The five horizons fall near a straight line on an age versus depth plot (Figure 2). The net sedimentation was thus probably constant at $4.7 \mathrm{~cm}$ per thousand years, and our correlations of the two climatic events are likely to be correct.

TABLE

Informal Planktonic Foraminiferal Zones and Ages at Site 284 and Correlations with Site 207 Zones (Kennett, 1973) and New Zealand Stages

\begin{tabular}{|c|c|c|c|}
\hline Site 207 Zones & Informal Zones & New Zealand Stages & Age \\
\hline $\begin{array}{l}\text { Globorotalia } \\
\text { truncatulinoides }\end{array}$ & \multirow{2}{*}{1} & \multirow{2}{*}{ Hautawan } & \multirow{2}{*}{ Pleistocene } \\
\hline $\begin{array}{l}\text { Globorotalia } \\
\text { truncatulinoides- } \\
\text { tosaensis overlap }\end{array}$ & & & \\
\hline $\begin{array}{l}\text { Globorotalia } \\
\text { tosaensis }\end{array}$ & \multirow{2}{*}{2} & Mangapanian & \multirow{4}{*}{ Pliocene } \\
\hline $\begin{array}{l}\text { Globorotalia } \\
\text { inflata }\end{array}$ & & Waipipian & \\
\hline $\begin{array}{l}\text { Globorotalia } \\
\text { crassaformis }\end{array}$ & \multirow[b]{2}{*}{3} & \multirow{2}{*}{ Opoitian } & \\
\hline $\begin{array}{l}\text { Globorotalia } \\
\text { puncticulata }\end{array}$ & & & \\
\hline $\begin{array}{l}\text { Globorotalia } \\
\text { conomiozea }\end{array}$ & 4 & Kapitean & \multirow{2}{*}{$\begin{array}{c}\text { Late } \\
\text { Miocene }\end{array}$} \\
\hline $\begin{array}{l}\text { Globigerina } \\
\text { nepenthes }\end{array}$ & 5 & Tongaporutuan & \\
\hline
\end{tabular}




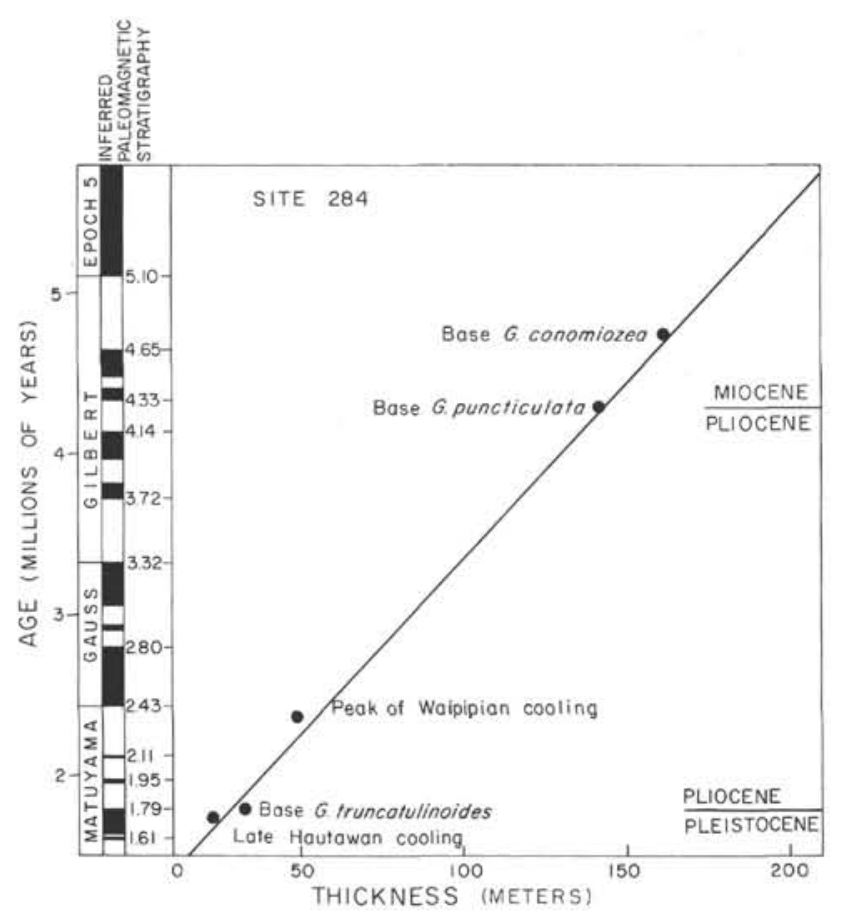

Figure 2. Sedimentation rate diagram. Ages of the biostratigraphic and paleoclimatic events shown have been determined by paleomagnetic dating in New Zealand marine sequences (Kennett and Watkins, in press; Kennett et al., 1971) and have enabled the inferred paleomagnetic stratigraphy to be determined for the Site 284 sequence.

\section{PLANKTONIC FORAMINIFERAL FAUNAL TRENDS}

\section{Techniques}

The samples examined are distributed at regular intervals of 1.5 meters through the sequence except at short intervals of no recovery. They were prepared for examination by drying, weighing, soaking with boiling calgon solution, and washing over a $63 \mu$ Tyler mesh sieve. Unbiased splits of approximately 300 specimens were taken from the fraction $>175 \mu$ separated by dry sieving. The specimens in the sample splits were counted to determine the frequency of each species. Percentages of the coiling morphotypes of Neogloboquadrina pachyderma were also determined by counting approximately 100 specimens in the fraction $>125 \mu$. The frequencies (\%) of each species are recorded in Table 2, and various computations of the counts are recorded in Table 3 .

\section{Coiling Ratios}

Coiling in populations of Neogloboquadrina pachyder$m a$ is primarily sinistral in the late Miocene and early Pliocene (Figure 3 ) and dextral in the middle Pliocene to Recent. Within the late Miocene Tongaporutuan and Kapitean stages, the coiling is fairly constantly $(>70 \%)$ sinistral with only minor fluctuations. Throughout the Pliocene, major oscillations in coiling ratios are superimposed upon a general upward trend of increased dextral forms. In the latest Pliocene and early Pleistocene, the coiling is fairly constantly $(>70 \%)$ dextral. In DDP sites in warmer waters to the north (Sites 207, cool-subtropical, South Pacific; Site 206, warmsubtropical, South Pacific; Site 208, warm subtropical, South Pacific; Site 264, warm-subtropical, southern Indian Ocean), $N$. pachyderma populations are also dominantly sinistral in the late Miocene and early Pliocene. The record in these cores indicates that dextral populations moved southward during the early Pliocene as they increased their cold tolerance through time, and slowly displaced sinistral populations to the south. Thus, the environmental tolerance of sinistral and dextral populations of $N$. pachyderma changed between the late Miocene and middle Pliocene. As a result, coilingratios are of no value for paleotemperature analyses in the late Miocene and early Pliocene as previously used by various workers such as Bandy et al. (1971), Ingle (1967), Kennett (1967), and Jenkins (1967). It appears that sinistral coiling was inherited by $N$. pachyderma from its late middle to early late Miocene ancestor Globorotalia continuosa Blow as was suggested by Jenkins (1967). This explains the anomalous sinistral populations recorded by Devereux et al. (1970) in subtropical faunas of Gauss age at Mangaopari Stream, eastern New Zealand.

\section{Percentage Frequencies}

Frequencies of $N$. pachyderma (Figure 3) are low from the base of the sequence up to 170 meters near the top of the late Miocene Tongaporutuan Stage; from 115 to 60 meters representing most of the early and middle Pliocene Opoitian Stage; and from 40 meters to the top of the sequence representing the latest Pliocene and Quaternary. Frequencies of $N$. pachyderma are high from 170 to 115 meters representing the latest Miocene and basal Pliocene (Kapitean and lower Opoitian stages), and from 60 to 40 meters representing the late Pliocene Waipipian Stage. Maximum frequencies do not exceed about $30 \%$ of the total planktonic foraminiferal population, and this is in marked contrast to eastern New Zealand sites where the frequencies rise to $50 \%$ to $60 \%$ in cold phases (Devereux et al., 1970; Lienert et al., 1972; Kennett and Watkins, in press).

Much consistent evidence exists to show that $N$. pachyderma is the most useful planktonic foraminifer in middle to high latitudes for recording paleoclimatic oscillations during the late Cenozoic (Bandy et al., 1971; Ingle, 1967, 1973; Devereux et al. 1970; Kennett et al., 1971; Lienert et al., 1972; Kennett and Watkins, in press). Oscillations in the frequency of this species marks particularly severe cool episodes during the latest Miocene and earliest Pliocene (Kapitean-early Opoitian stages), during the late Pliocene (Waipipian Stage), and a brief cooling episode during the early Pleistocene (Figure 3 ). The most prolonged and severe cooling based on this criterion occurred during the Kapitean to early Opoitian stages. The cool episodes are separated by warmer intervals, the most prolonged and distinct of which are during the earlier late Miocene (Tongaporu- 
TABLE 2

Planktonic Foraminiferal Data for Site 284, Informal Zones, New Zealand Stages, and Age

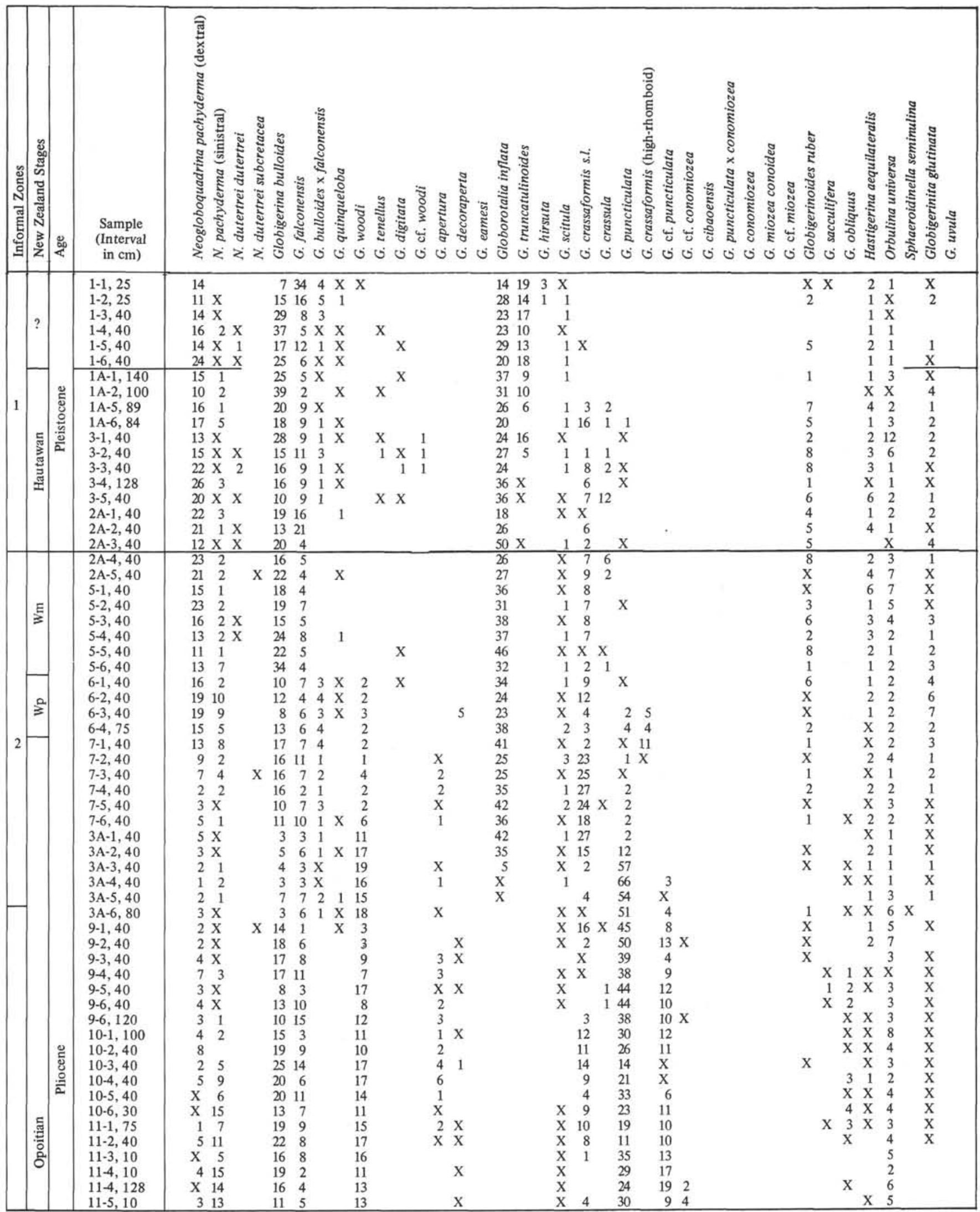


TABLE 2 - Continued

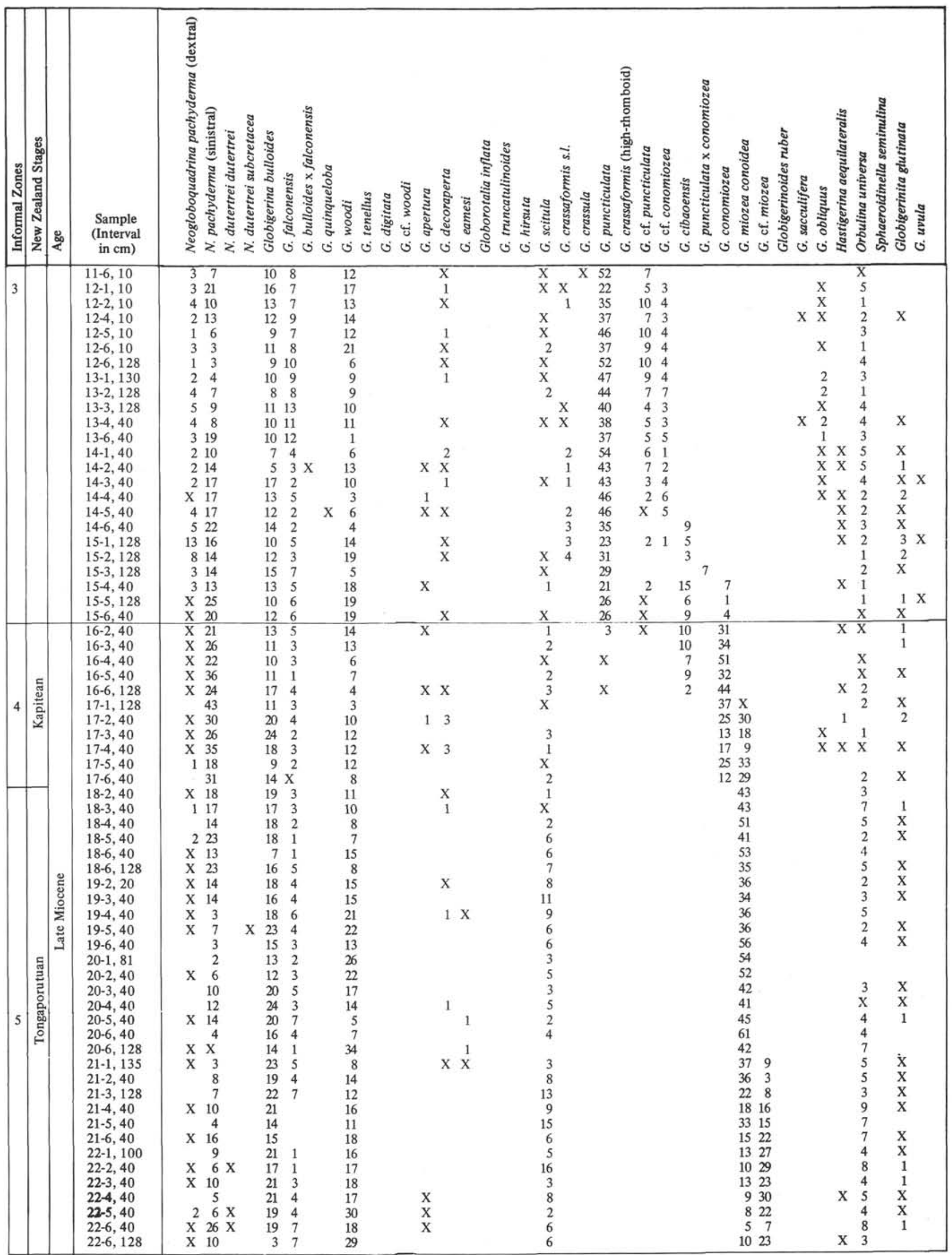


TABLE 3

Planktonic Foraminiferal Data for Site 284

\begin{tabular}{|c|c|c|c|c|c|c|c|c|c|c|c|}
\hline $\begin{array}{c}\text { Sample } \\
\text { (Interval in } \mathrm{cm} \text { ) }\end{array}$ & 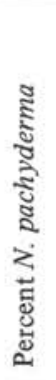 & 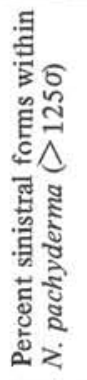 & 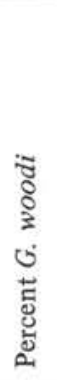 & 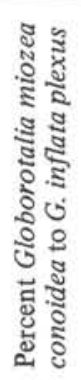 & 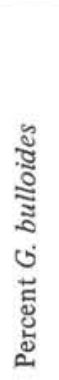 & 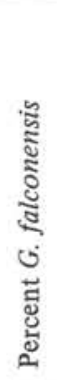 & 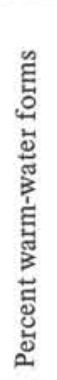 & 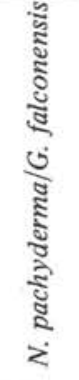 & 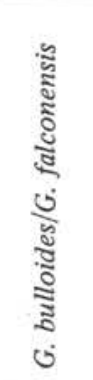 & 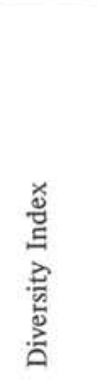 & 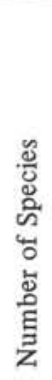 \\
\hline $1-1,25$ & 14 & 8 & & 14 & 7 & 34 & 3 & 0.41 & 0.21 & 2.68 & 15 \\
\hline $1-2,25$ & 12 & 14 & & 28 & 15 & 16 & 4 & 0.75 & 0.94 & 2.84 & 14 \\
\hline $1-3,40$ & 15 & 27 & & 23 & 29 & 8 & 1 & 1.88 & 3.63 & 2.47 & 10 \\
\hline $1-4,40$ & 18 & 11 & & 23 & 37 & 5 & 2 & 3.60 & 7.40 & 2.46 & 13 \\
\hline $1-5,40$ & 14 & 14 & & 29 & 17 & 12 & 9 & 1.18 & 1.42 & 2.83 & 16 \\
\hline $1-6,40$ & 24 & 4 & & 20 & 25 & 6 & 2 & 4.00 & 4.17 & 2.52 & 13 \\
\hline $1 \mathrm{~A}-1,140$ & 16 & 9 & & 37 & 25 & 5 & 3 & 3.20 & 5 & 2.40 & 13 \\
\hline $1 \mathrm{~A}-2,100$ & 11 & 28 & & 31 & 39 & 2 & & 5.50 & 16.50 & 2.20 & 11 \\
\hline $1 \mathrm{~A}-5,89$ & 17 & 28 & & 26 & 20 & 9 & 11 & 1.89 & 2.22 & 2.91 & 14 \\
\hline $1 \mathrm{~A}-6,84$ & 21 & 33 & & 21 & 18 & 9 & 6 & 2.33 & 2 & 3 & 15 \\
\hline $3-1,40$ & 12 & 21 & & 24 & 28 & 9 & 3 & 1.33 & 3.11 & 2.66 & 16 \\
\hline $3-2,40$ & 16 & 25 & & 27 & 15 & 11 & 12 & 1.46 & 1.36 & 3.07 & 18 \\
\hline $3-3,40$ & 22 & 24 & & 25 & 16 & 9 & 10 & 2.44 & 1.78 & 2.95 & 18 \\
\hline $3-4,128$ & 29 & 10 & & 36 & 16 & 9 & 2 & 3.22 & 1.78 & 2.39 & 14 \\
\hline $3-5,40$ & 20 & 7 & & 36 & 10 & 9 & 12 & 2.22 & 1.11 & 2.72 & 17 \\
\hline $2 \mathrm{~A}-1,40$ & 25 & 22 & & 18 & 19 & 16 & 6 & 1.56 & 1.19 & 2.84 & 12 \\
\hline $2 \mathrm{~A}-2,40$ & 22 & 10 & & 26 & 13 & 21 & 9 & 1.05 & 0.62 & 2.63 & 11 \\
\hline $2 \mathrm{~A}-3,40$ & 12 & 33 & & 50 & 20 & 4 & 6 & 3.00 & 5 & 2.18 & 12 \\
\hline $2 \mathrm{~A}-5,40$ & 22 & 13 & & 27 & 22 & 4 & 5 & 5.50 & 5.50 & 2.74 & 14 \\
\hline $5-1,40$ & 16 & 15 & & 36 & 18 & 4 & 6 & 4.00 & 4.50 & 2.51 & 11 \\
\hline $5-2,40$ & 25 & 16 & & 31 & 19 & 7 & 4 & 3.57 & 2.71 & 2.54 & 12 \\
\hline $5-3,40$ & 18 & 13 & & 38 & 15 & 5 & 9 & 3.60 & 3 & 2.64 & 12 \\
\hline $5-4,40$ & 15 & 21 & & 37 & 24 & 8 & 5 & 1.88 & 3 & 2.61 & 13 \\
\hline $5-5,40$ & 12 & 26 & & 46 & 22 & 5 & 11 & 2.40 & 4.40 & 2.28 & 13 \\
\hline $5-6,40$ & 20 & 37 & & 32 & 34 & 4 & 2 & 5.00 & 8.50 & 2.40 & 12 \\
\hline $6-1,40$ & 18 & 44 & 2 & 35 & 10 & 7 & 8 & 2.57 & 1.43 & 2.89 & 16 \\
\hline $6-2,40$ & 30 & 49 & 2 & 24 & 12 & 4 & 3 & 7.50 & 3 & 2.98 & 14 \\
\hline $6-3,40$ & 28 & 50 & 3 & 25 & 8 & 6 & 2 & 4.67 & 1.33 & 3.24 & 17 \\
\hline $6-4,75$ & 20 & 34 & 2 & 41 & 13 & 6 & 2 & 3.33 & 2.17 & 2.82 & 15 \\
\hline $7-1,40$ & 9 & 41 & 2 & 41 & 17 & 7 & 2 & 1.29 & 2.43 & 2.74 & 15 \\
\hline $7-2,40$ & 11 & 45 & 1 & 26 & 16 & 11 & 2 & 1.00 & 1.46 & 2.89 & 16 \\
\hline $7-3,40$ & 11 & 33 & 4 & 26 & 16 & 7 & 2 & 1.57 & 2.29 & 2.91 & 16 \\
\hline $7-4,40$ & 4 & 65 & 2 & 37 & 16 & 2 & 5 & 2.00 & 0.8 & 2.53 & 15 \\
\hline $7-5,40$ & 4 & 55 & 2 & 46 & 10 & 7 & 3 & 0.57 & 1.43 & 2.47 & 16 \\
\hline $7-6,40$ & 6 & 26 & 6 & 38 & 11 & 10 & 5 & 0.60 & 1.10 & 2.81 & 17 \\
\hline $3-1,40$ & 6 & 54 & 11 & 44 & 3 & 3 & & 2.00 & 1 & 2.10 & 13 \\
\hline $3-2,40$ & 3 & 37 & 17 & 36 & 5 & 6 & 3 & 0.50 & 0.83 & 2.75 & 15 \\
\hline $3-3,40$ & 2 & 55 & 19 & 62 & 4 & 3 & 3 & 0.68 & 1.33 & 2.10 & 16 \\
\hline $3-4,40$ & 3 & 63 & 16 & 66 & 3 & 3 & 1 & 1.00 & 1 & 1.82 & 15 \\
\hline $3-5,40$ & 4 & 76 & 15 & 55 & 7 & 7 & 1 & 0.57 & 1 & 2.26 & 14 \\
\hline $3-6,80$ & 3 & 61 & 18 & 51 & 3 & 6 & 3 & 0.50 & .50 & 2.32 & 17 \\
\hline $9-1,40$ & 3 & 47 & 3 & 46 & 14 & 1 & 2 & 3.00 & 14 & 2.52 & 16 \\
\hline $7-2,40$ & 2 & 45 & 3 & 50 & 18 & 6 & 4 & 0.33 & 3 & 2.64 & 14 \\
\hline $9-3,40$ & 5 & 36 & 9 & 39 & 17 & 8 & 1 & 0.63 & 2.13 & 2.80 & 13 \\
\hline $9-4,40$ & 10 & 30 & 7 & 38 & 17 & 11 & 2 & 0.91 & 1.55 & 3.11 & 15 \\
\hline $9-5,40$ & 4 & 39 & 17 & 44 & 8 & 3 & 4 & 1.33 & 2.67 & 2.99 & 16 \\
\hline $9-6,40$ & 5 & 29 & 8 & 44 & 13 & 10 & 3 & 0.50 & 1.30 & 3.03 & 14 \\
\hline $9-6,120$ & 4 & 30 & 12 & 38 & 10 & 15 & & 0.27 & 0.67 & 3.03 & 14 \\
\hline $10-1,100$ & 6 & 34 & 11 & 30 & 15 & 3 & & 2.00 & 5 & 2.89 & 14 \\
\hline $10-2,40$ & 8 & 32 & 10 & 26 & 19 & 9 & & 0.89 & 2.11 & 2.90 & 12 \\
\hline $10-3,40$ & 6 & 66 & 17 & 14 & 25 & 14 & 1 & 0.43 & 1.79 & 2.93 & 14 \\
\hline $10-4,40$ & 13 & 66 & 17 & 21 & 20 & 6 & & 2.17 & 3.33 & 3.09 & 13 \\
\hline $10-5,40$ & 6 & 75 & 14 & 33 & 20 & 11 & & 0.55 & 1.82 & 2.72 & 13 \\
\hline $10-6,30$ & 15 & 80 & 11 & 23 & 13 & 7 & 4 & 2.14 & 1.86 & 3.08 & 14 \\
\hline $11-1,75$ & 8 & 79 & 15 & 19 & 19 & 9 & 3 & 0.89 & 2.11 & 3.23 & 16 \\
\hline $11-2,40$ & 16 & 61 & 17 & 11 & 22 & 8 & 1 & 2.00 & 2.75 & 3.06 & 14 \\
\hline $11-3,10$ & 6 & 81 & 16 & 35 & 16 & 8 & & 0.75 & 2 & 2.58 & 10 \\
\hline $11-4,10$ & 18 & 82 & 11 & 29 & 19 & 2 & & 9.00 & 9.50 & 2.59 & 10 \\
\hline $11-4,128$ & 14 & 77 & 13 & 24 & 16 & 4 & & 3.50 & 4 & 2.73 & 11 \\
\hline $11-5,10$ & 16 & 65 & 13 & 30 & 11 & 5 & & 3.20 & 2.20 & 2.93 & 13 \\
\hline $11-5,10$ & 16 & 65 & 13 & 30 & 11 & 5 & & 3.20 & 2.20 & 2.93 & 13 \\
\hline $11-6,10$ & 10 & 69 & 12 & 52 & 10 & 8 & & 1.25 & 1.25 & 2.19 & 11 \\
\hline $12-1,10$ & 24 & 73 & 17 & 22 & 16 & 7 & 1 & 3.43 & 2.29 & 2.89 & 13 \\
\hline
\end{tabular}


TABLE 3-Continued.

\begin{tabular}{|c|c|c|c|c|c|c|c|c|c|c|c|}
\hline $\begin{array}{c}\text { Sample } \\
\text { (Interval in cm) }\end{array}$ & 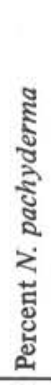 & 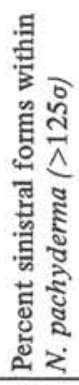 & 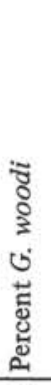 & 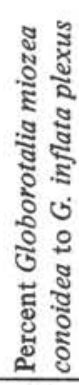 & 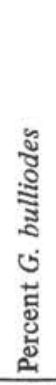 & 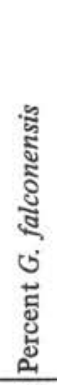 & 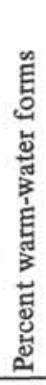 & 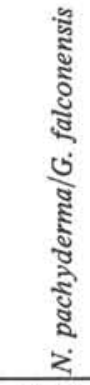 & 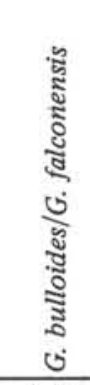 & 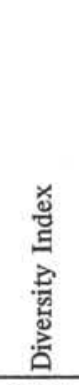 & 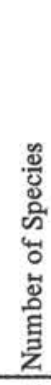 \\
\hline $12-2,10$ & 14 & 68 & 13 & 35 & 13 & 7 & 1 & 2.00 & 1.86 & 2.74 & 12 \\
\hline $12-4,10$ & 15 & 73 & 14 & 37 & 12 & 9 & 1 & 1.67 & 1.33 & 2.65 & 13 \\
\hline $12-5,10$ & 7 & 66 & 12 & 46 & 9 & 7 & & 1.00 & 1.29 & 2.50 & 11 \\
\hline $12-6,10$ & 6 & 65 & 21 & 37 & 11 & 8 & 1 & 0.75 & 1.38 & 2.62 & 12 \\
\hline $12-6,128$ & 4 & & 6 & 52 & 9 & 10 & & 0.40 & 0.90 & 2.31 & 11 \\
\hline $13-1,130$ & 6 & 52 & 10 & 47 & 10 & 9 & 2 & 0.68 & 1.11 & 2.51 & 12 \\
\hline $13-2,128$ & 11 & 40 & 9 & 44 & 8 & 8 & & 1.38 & 1 & 2.61 & 11 \\
\hline $13-3,128$ & 15 & 61 & 10 & 40 & 11 & 13 & 1 & 1.15 & 0.85 & 2.62 & 11 \\
\hline $13-4,40$ & 13 & 46 & 11 & 38 & 10 & 11 & & 1.18 & 0.91 & 2.83 & 15 \\
\hline $13-6,40$ & 22 & 76 & 1 & 37 & 10 & 12 & & 1.83 & 0.83 & 2.58 & 10 \\
\hline $14-1,40$ & 12 & 83 & 6 & 54 & 7 & 4 & 1 & 3.00 & 1.75 & 2.38 & 14 \\
\hline $14-2,40$ & 15 & 86 & 13 & 45 & 5 & 3 & 1 & 5.00 & 1.67 & 2.69 & 16 \\
\hline $14-3,40$ & 19 & 85 & 10 & 47 & 17 & 2 & 1 & 9.50 & 8.50 & 2.60 & 15 \\
\hline $14-4,40$ & 17 & 89 & 3 & 46 & 13 & 5 & 1 & 3.40 & 2.60 & 2.42 & 13 \\
\hline $14-5,40$ & 21 & 64 & 6 & 46 & 12 & 2 & 1 & 10.50 & 6 & 2.46 & 15 \\
\hline $14-6,40$ & 27 & 61 & 4 & 35 & 14 & 2 & 1 & 13.50 & 7 & 2.62 & 11 \\
\hline $15-1,128$ & 29 & 53 & 14 & 24 & 10 & 5 & & 5.80 & 2 & 3.12 & 15 \\
\hline $15-2,128$ & 22 & 52 & 19 & 33 & 12 & 3 & & 7.33 & 4 & 2.71 & 12 \\
\hline $15-3,128$ & 16 & 56 & 5 & 33 & 15 & 7 & & 2.29 & 2.14 & 2.78 & 10 \\
\hline $15-4,40$ & 15 & 53 & 18 & 29 & 13 & 5 & & 3.00 & 2.60 & 2.93 & 13 \\
\hline $15-5,128$ & 25 & 85 & 19 & 28 & 10 & 6 & & 4.17 & 1.67 & 2.62 & 12 \\
\hline $15-6,40$ & 21 & 75 & 19 & 31 & 12 & 6 & & 3.50 & 2 & 2.70 & 13 \\
\hline $16-2,40$ & 21 & 82 & 14 & 33 & 13 & 5 & & 4.20 & 2.60 & 2.63 & 14 \\
\hline $16-3,40$ & 26 & 87 & 13 & 33 & 11 & 3 & & 8.67 & 3.68 & 2.39 & 9 \\
\hline $16-4,40$ & 22 & 92 & 6 & 51 & 10 & 3 & & 7.33 & 3.33 & 2.02 & 10 \\
\hline $16-5,40$ & 36 & 95 & 7 & 32 & 11 & 1 & & 36.00 & 11 & 2.18 & 10 \\
\hline $16-6,128$ & 24 & 89 & 4 & 44 & 17 & 4 & & 6.00 & 4.25 & 2.20 & 13 \\
\hline $17-1,128$ & 43 & 93 & 3 & 37 & 11 & 3 & & 14.33 & 3.68 & 1.82 & 9 \\
\hline $17-2,40$ & 31 & 87 & 10 & 56 & 20 & 4 & & 7.75 & 5 & 2.53 & 11 \\
\hline $17-3,40$ & 26 & 89 & 12 & 31 & 24 & 2 & & 13.00 & 12 & 2.52 & 10 \\
\hline $17-4,40$ & 35 & 86 & 12 & 26 & 18 & 3 & & 11.67 & 6 & 2.55 & 14 \\
\hline $17-5,40$ & 19 & 91 & 12 & 58 & 9 & 2 & & 9.50 & 4.50 & 2.25 & 8 \\
\hline $17-6,40$ & 31 & 91 & 8 & 40 & 14 & & & & 30 & 2.31 & 9 \\
\hline $18-2,40$ & 18 & 85 & 11 & 43 & 19 & 3 & & 6.00 & 6.33 & 2.16 & 9 \\
\hline $18-3,40$ & 18 & 82 & 10 & 43 & 17 & 3 & & 6.00 & 5.68 & 2.31 & 10 \\
\hline $18-4,40$ & 13 & 87 & 8 & 51 & 18 & 2 & & 6.50 & 9 & 2.01 & 8 \\
\hline $18-5,40$ & 24 & 77 & 7 & 41 & 18 & 1 & & 24.00 & 18 & 2.23 & 9 \\
\hline $18-6,40$ & 13 & 92 & 15 & 53 & 7 & 1 & & 13.00 & 7 & 2.01 & 8 \\
\hline $18-6,128$ & 4 & 90 & 8 & 35 & 16 & 5 & & 0.80 & 3.20 & 2.46 & 9 \\
\hline $19-2,20$ & 15 & 84 & 15 & 36 & 18 & 4 & & 3.75 & 4.50 & 2.48 & 10 \\
\hline $19-3,40$ & 15 & 88 & 15 & 34 & 16 & 4 & & 3.75 & 4 & 2.46 & 9 \\
\hline $19-4,40$ & 4 & 79 & 21 & 36 & 18 & 6 & & 0.67 & 3 & 2.43 & 10 \\
\hline $19-5,40$ & 7 & 77 & 22 & 36 & 23 & 4 & & 1.75 & 5.75 & 2.34 & 10 \\
\hline $19-6,40$ & 3 & 84 & 13 & 56 & 15 & 3 & & 1.00 & 5 & 1.96 & 8 \\
\hline $20-1,81$ & 2 & 80 & 26 & 54 & 13 & 2 & & 1.00 & 6.50 & 1.30 & 6 \\
\hline $20-2,40$ & 6 & 74 & 22 & 52 & 12 & 3 & & 2.00 & 4 & 1.93 & 7 \\
\hline $20-3,40$ & 10 & 76 & 17 & 42 & 20 & 5 & & 2.00 & 4 & 2.21 & 8 \\
\hline $20-4,40$ & 12 & 86 & 14 & 46 & 24 & 3 & & 4.00 & 8 & 2.20 & 9 \\
\hline $20-5,40$ & 15 & 91 & 5 & 45 & 20 & 7 & & 2.14 & 2.86 & 2.18 & 10 \\
\hline $20-6,40$ & 4 & 77 & 7 & 61 & 16 & 4 & & 1.00 & 4 & 1.81 & 7 \\
\hline $20-6,128$ & 3 & 80 & 34 & 42 & 14 & 1 & & 3.00 & 14 & 1.84 & 8 \\
\hline $21-1,135$ & 4 & 76 & 8 & 47 & 23 & 5 & & 0.80 & 4.60 & 2.46 & 12 \\
\hline $21-2,40$ & 8 & 70 & 14 & 40 & 19 & 4 & & 2.00 & 4.75 & 2.62 & 9 \\
\hline $21-3,128$ & 7 & 71 & 12 & 30 & 22 & 7 & & 1.00 & 3.14 & 2.96 & 9 \\
\hline $21-4,40$ & 10 & 80 & 16 & 34 & 21 & & & & & 2.76 & 9 \\
\hline $21-5,40$ & 4 & 70 & 11 & 48 & 14 & & & & & 2.49 & 7 \\
\hline $21-6,40$ & 16 & 84 & 18 & 37 & 15 & & & & & 2.71 & 9 \\
\hline $22-1,100$ & 9 & 88 & 16 & 39 & 21 & 1 & & 9.00 & 21 & 2.69 & 9 \\
\hline $22-2,40$ & 6 & 84 & 17 & 39 & 17 & 1 & & 6.00 & 17 & 2.76 & 11 \\
\hline $22-3,40$ & 10 & 81 & 18 & 36 & 21 & 3 & & 3.33 & 7 & 2.82 & 10 \\
\hline $22-4,40$ & 5 & 77 & 17 & 39 & 21 & 4 & & 1.25 & 5.25 & 2.70 & 11 \\
\hline $22-5,40$ & 8 & 79 & 30 & 30 & 19 & 4 & & 2.00 & 4.75 & 2.70 & 12 \\
\hline $22-6,40$ & 26 & 88 & 18 & 12 & 19 & 7 & & 3.71 & 2.71 & 2.85 & 12 \\
\hline $22-6,128$ & 10 & 75 & 29 & 33 & 3 & 7 & & 1.43 & 0.43 & 2.85 & 10 \\
\hline
\end{tabular}




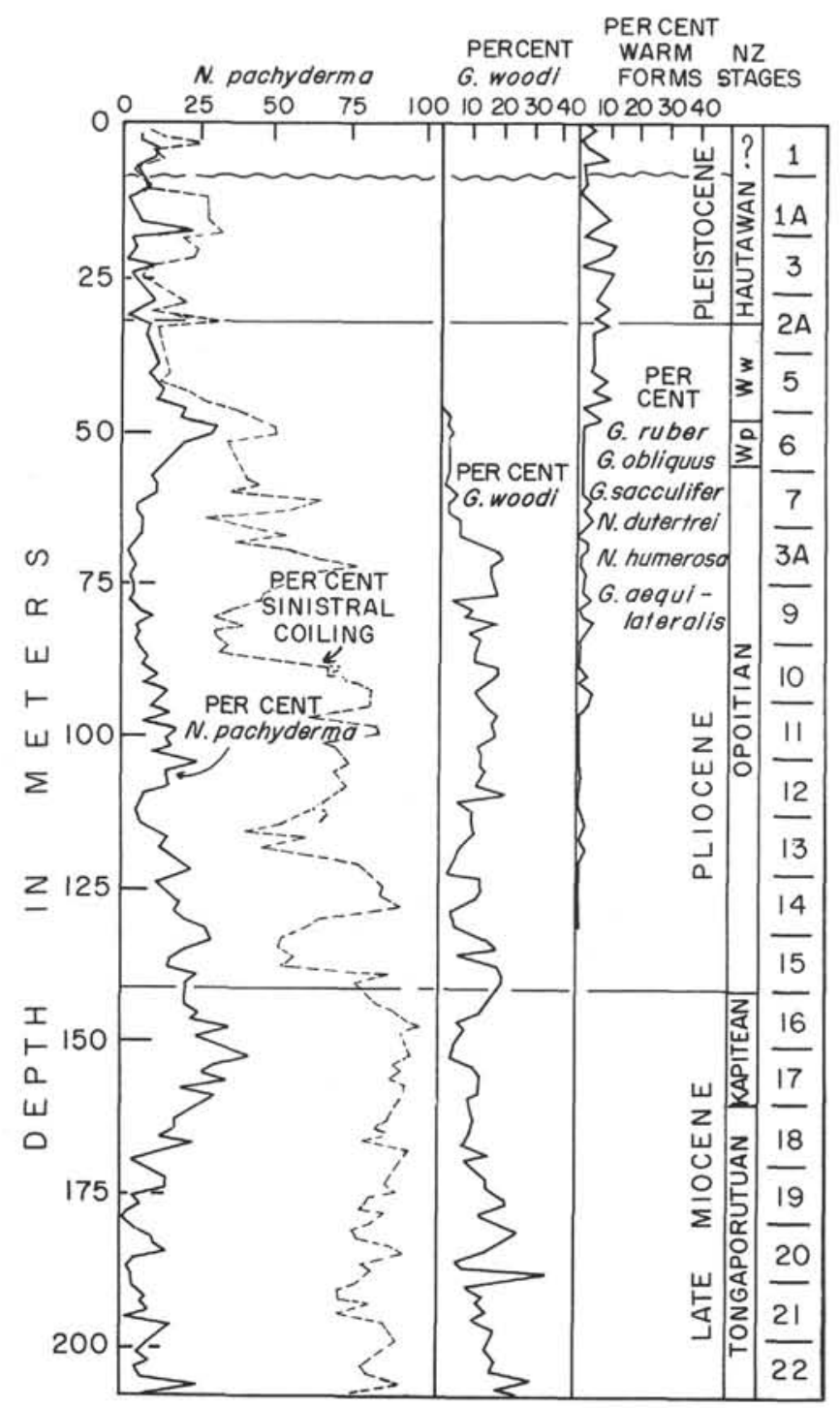

Figure 3. Planktonic foraminiferal parameters, age, and New Zealand stage correlations for Site 284. Frequency and coiling-ratio oscillations in Neogloboquadrina pachyderma at left; frequency oscillations also shown for Globigerina woodi and the sum of several distinctly warm-water species. Numbers at right are core numbers. $W p=$ Waipipian Stage; $W w=$ Mangapanian Stage. Position of middle Pleistocene disconformity is shown near top of sequence.

tuan Stage), and the middle Pliocene (late Opoitian Stage).

Changes in coiling ratio in $N$. pachyderma do not correspond with this species'frequency oscillations in much of the sequence. Large fluctuations in coiling ratios in the Pliocene are not mirrored by the frequency oscillations. Furthermore, anomalously high percentages of sinistral forms in the middle Pliocene coincide with distinctly warm intervals as indicated by low frequencies of $N$. pachyderma and other criteria and is thus similar to trends already noted by Devereux et al. (1970) in eastern New Zealand. During the late Pliocene and younger part of the Site 284 sequence (Figure 3), fre- quency oscillations in $N$. pachyderma generally correspond with coiling-ratio oscillations, and hence coiling ratios appear to be sensitive to paleoclimatic change for this time interval.

Frequencies of Globigerina woodi Jenkins (Figure 3) vary from zero to a maximum of $40 \%$, and most commonly between about $5 \%$ and $30 \%$. The frequency variations in $G$. woodi are in general reciprocal with those displayed by $N$. pachyderma. At the beginning of the Waipipian cooling, this species decreases dramatically and disappears just after the end of it. The frequency of $G$. woodi is particularly low through much of the Kapitean cooling and at intervals in the early Pliocene. The reduction and disappearance of $G$. woodi was obviously controlled by late Pliocene cooling. In DSDP sites in warmer waters to the north (Kennett, 1973) G. woodi disappears later within the late Pliocene or early Pleistocene.

Planktonic foraminifera that are restricted to presentday warm subtropical and warmer waters (Globigerinoides ruber, Globigerinoides sacculifer, Neogloboquadrina dutertrei, and Hastigerina aequilateralis) and related fossil forms (Globigerinoides obliquus and Neogloboquadrina humerosa) in total are seldom more abundant than $10 \%$ of the total planktonic foraminiferal population (Figure 3). These forms are absent during the late Miocene, rare in the early Pliocene and in the cool intervals during the Waipipian Stage and rare in the Pleistocene. The average abundance increased towards the early Pleistocene suggesting an overall average warming through the late Cenozoic. This is inconsistent with trends suggested by late Cenozoic molluscan change in New Zealand (Fleming, 1962 ; Beu, in press). It is possible that the upward increase in importance of these warm-water forms is due to increase in their tolerance to cold water. On the other hand it seems unlikely that all these forms would similarly change their environmental tolerance through time. The discrepancy needs to be resolved by additional work.

Frequencies of the forms of Globorotalia that make up the $G$. miozea conoidea to $G$. inflata evolutionary lineage ( $G$. cf. miozea to $G$. miozea conoidea to $G$. conomiozea to $G$. puncticulata to $G$. inflata), which are important constituents in temperate southern latitudes during the late Cenozoic are shown in Figure 4. This group of species makes up $10 \%$ to $60 \%$ of the total population, with frequent large oscillations about a mean of $38 \%$. The frequency variations do not show any particular relations with those of $N$. pachyderma and $G$. woodi. At the latitude of Site 284 this Globorotalia group is not particularly sensitive to paleotemperature change, but at higher and lower latitudes nearer the margins of its latitudinal range, frequency oscillations within the group should serve as a useful paleotemperature criterion (Kennett, 1970). Furthermore, interpretation of the paleoecology of the group is complicated because of its rapid evolution and by potentially different environmental relations of the members of the lineage.

Variations in the frequencies of Globigerina bulloides and Globigerina falconensis appear to be random (Figure 4) and are of no assistance in paleoclimatic interpretations. 


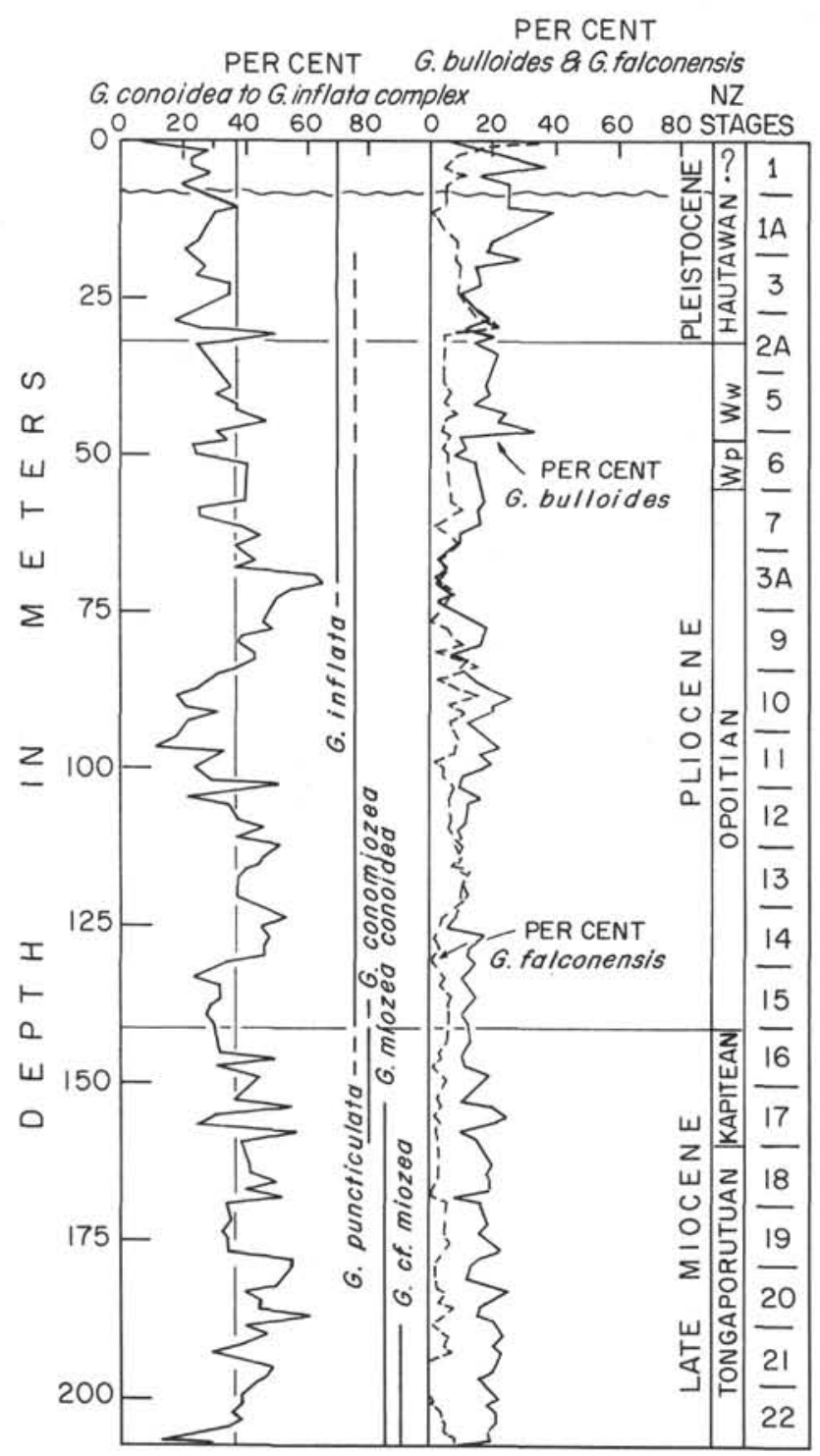

Figure 4. Planktonic foraminiferal parameters, age, and New Zealand Stage correlations for Site 284. Frequency oscillations in the Globorotalia miozea conoidea-G. inflata plexus at left include the sum of several over-lapping members of the evolutionary lineage, the ranges of which are shown; frequency oscillations also shown for Globigerina bulloides and Globigerina falconensis. Numbers at right are core numbers. $W p=$ Waipipian Stage; $W w=$ Mangapanian Stage. Position of middle Pleistocene disconformity is shown near top of sequence.

\section{Other Faunal Trends}

The ratio of abundances of the cool-water foraminifer $N$. pachyderma to the warmer-water form $G$. falconensis (Figure 5) clearly illustrates general paleotemperature trends at Site 284. A severe and rather prolonged cooling is recorded in the late Miocene and early Pliocene, with a brief warming episode over the Miocene-Pliocene boundary. Another severe cooling occurs during the Late Pliocene (Waipipian Stage). More brief cooling

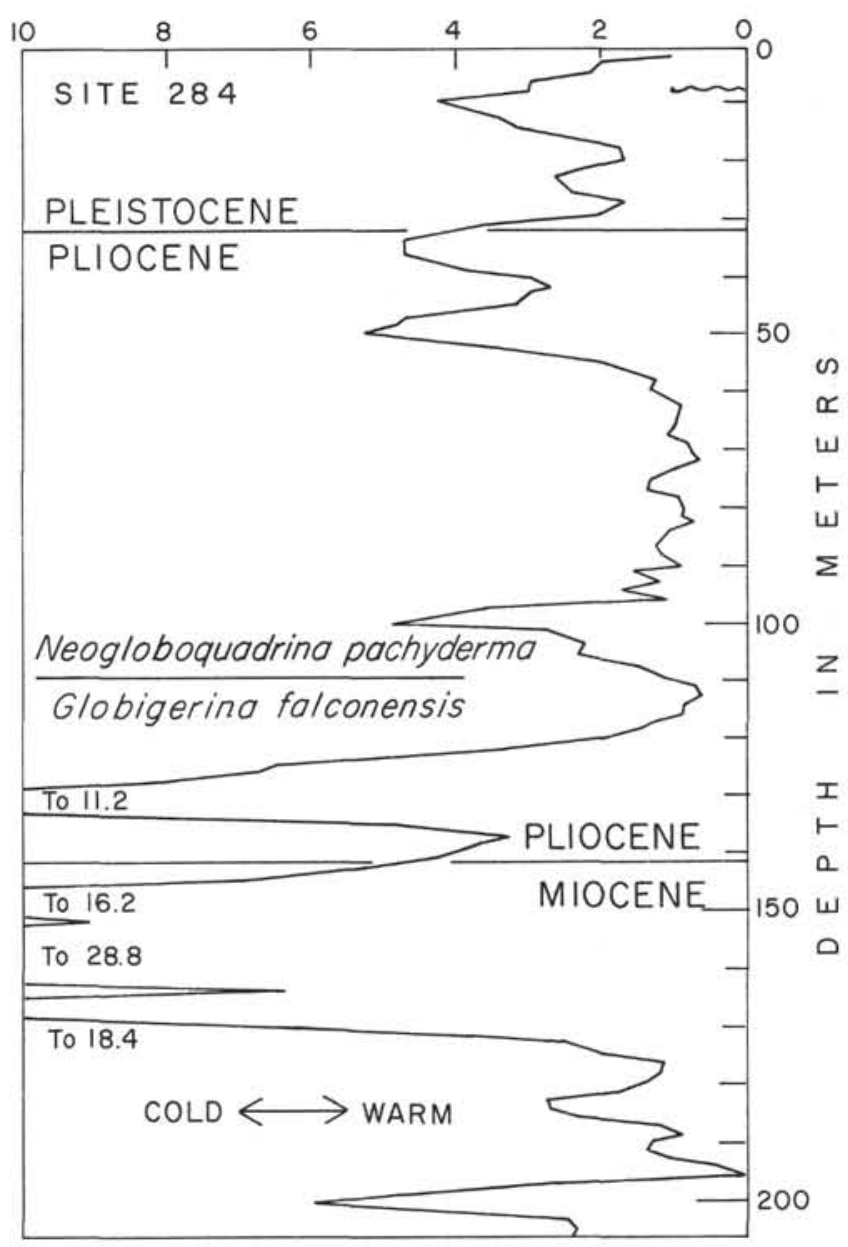

Figure 5. Ratio of Neogloboquadrina pachyderma/Globigerina falconensis at Site 284. Curve is a three-point running average. Increases in ratio represent colder intervals.

episodes occur during the Late Tongaporutuan, the early Pliocene, and the Pleistocene. Particularly warm intervals occurred during the earlier late Miocene and middle Pliocene (Figure 5). This pattern is very similar to that already determined for the New Zealand marine sequences (Devereux et al., 1970; Kennett et al., 1971; Lienert et al., 1972; Kennett and Watkins, in press).

The ratio of abundances of the cooler form Globigerina bulloides to the warmer form $G$. falconensis (Figure 6) is similar to the curve of the $N$. pachyder$m a / N$. falconensis ratio and to the New Zealand late Cenozoic paleoclimatic curve. In the present ocean these two forms intergrade as a geographic cline, with the $G$. bulloides morphotype dominating in subantarctic to cool-temperate areas and the $G$. Falconensis morphotype dominating in warm-temperature and warm-subtropical areas (Bé, 1969; Echols and Kennett, 1973).

Planktonic foraminiferal diversity has been used by several workers as a general criterion for estimating relative Cenozoic paleotemperatures (Jenkins, 1968; Berger and Parker, 1970; Margolis and Kennett, 1971). For the Site 284 sequence we have determined the diver- 


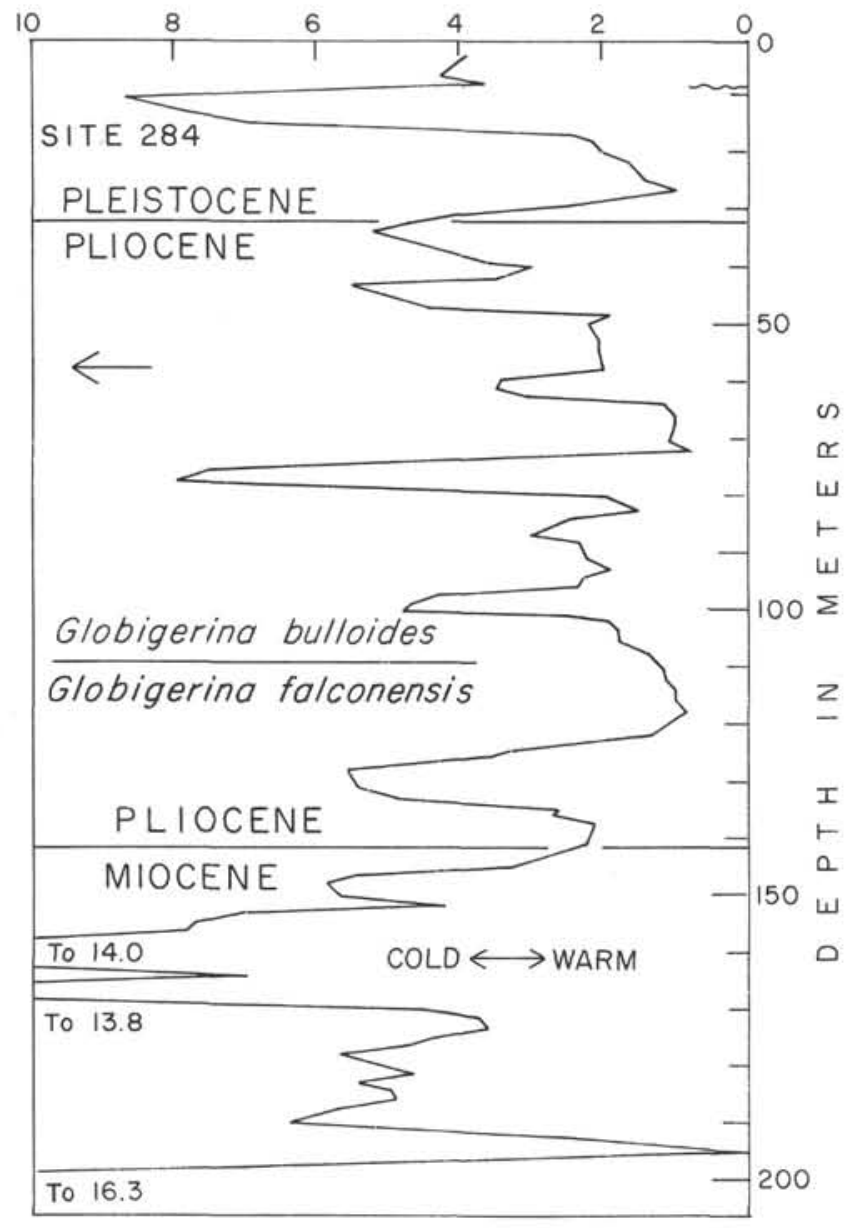

Figure 6. Ratio of Globigerina bulloides/Globigerina falconensis at Site 284. Curve is a three-point running average. Increases in ratio generally correspond with colder intervals.

sity (Figure 7) which is simply the number of species observed in a count of 300 specimens. We have calculated the Shannon-Wiener diversity index (Figure 7) which is influenced by the number of species present in the sample and the evenness of distribution of the individuals among these species.

Simple diversity varies from 6 to 17 species in fairly irregular fashion. The salient features, however, are generally low diversity throughout the late Miocene, and consistently higher diversities throughout the middle Pliocene. The diversity index (Figure 7) also shows low diversity throughout much of the late Miocene. Otherwise irregular variations occur throughout the Pliocene to Pleistocene, with no apparent relationship with paleotemperatures. Little correspondence exists between fluctuations of the diversity and the diversity index, except that both clearly show lower diversity through much of the late Miocene, as compared with the Pliocene and Pleistocene. The low diversity in the late Miocene occurs during both inferred warm (Tongaporutuan) and cold (Kapitean) intervals. This suggests that it results from a general paucity of late Miocene temperate species, rather than by simply cool

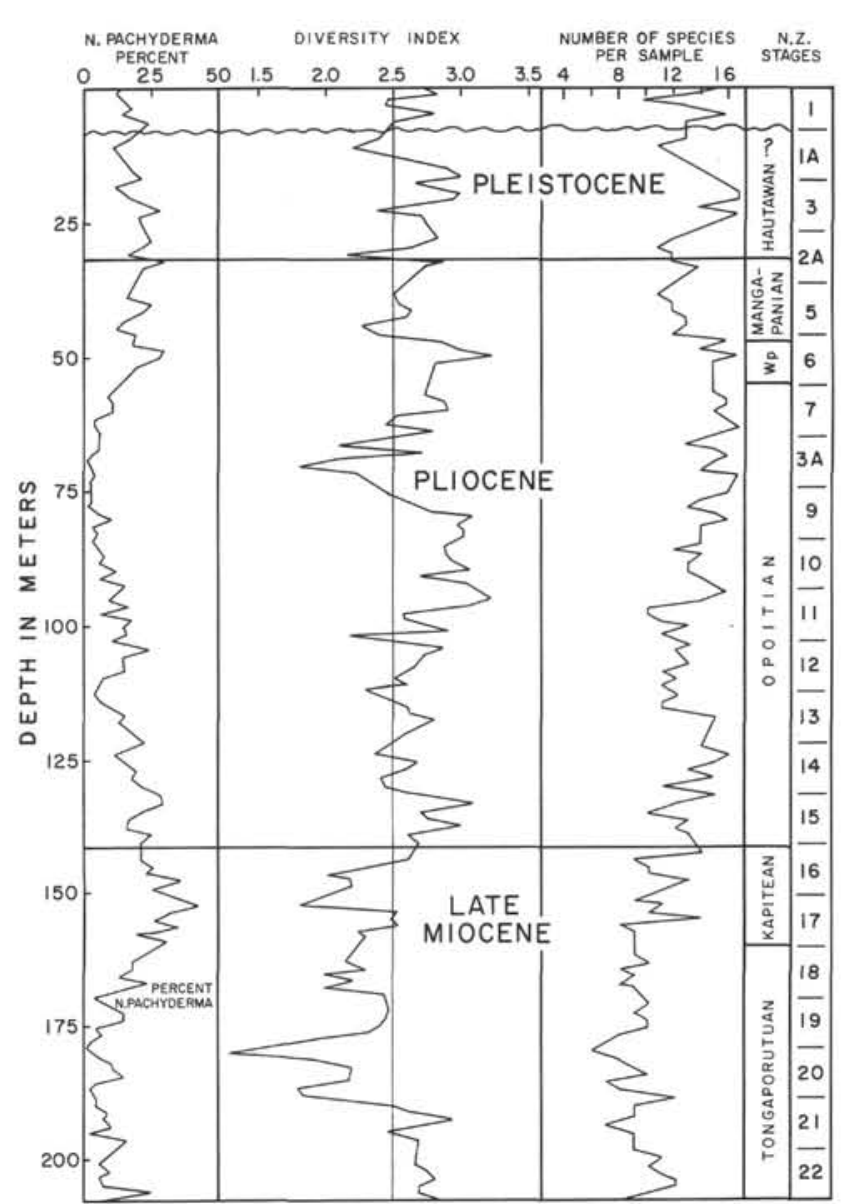

Figure 7. Diversity, Shannon-Wiener diversity index, and percent of the cool foraminifer N. pachyderma at Site 284. Diversity is simply the number of species in each faunal count of approximately 300 specimens. Numbers at right are core numbers. Wp=Waipipian Stage. Middle Pleistocene disconformity is shown near top of sequence.

temperatures. Consistently high diversity during the middle Pliocene is probably related to inferred warm conditions during this interval.

\section{DISCUSSION}

Frequency oscillations in the cool-water form $N$. pachyderma appear to be the most reliable planktonic foraminiferal criterion for determining paleoclimatic history in temperate southern latitudes. Paleoclimatic history based on this parameter is supported by fairly consistent reciprocal oscillations of the warmer species $G$. woodi, and by increases of the $N$. pachyderma/G. falconensis and $G$. bulloides $/ G$. falconensis ratios during cool episodes. Oscillations in the frequencies of other species appear to have occurred more or less randomly, with no apparent relation to inferred paleotemperature changes.

The paleoclimatic sequence at Site 284 is very similar to that reported from marine sections in eastern New Zealand (Devereux et al., 1970; Kennett et al., 1971; Lienert et al., 1972; Kennett and Watkins, in press), except that consistently lower frequencies of $N$. pachyder- 


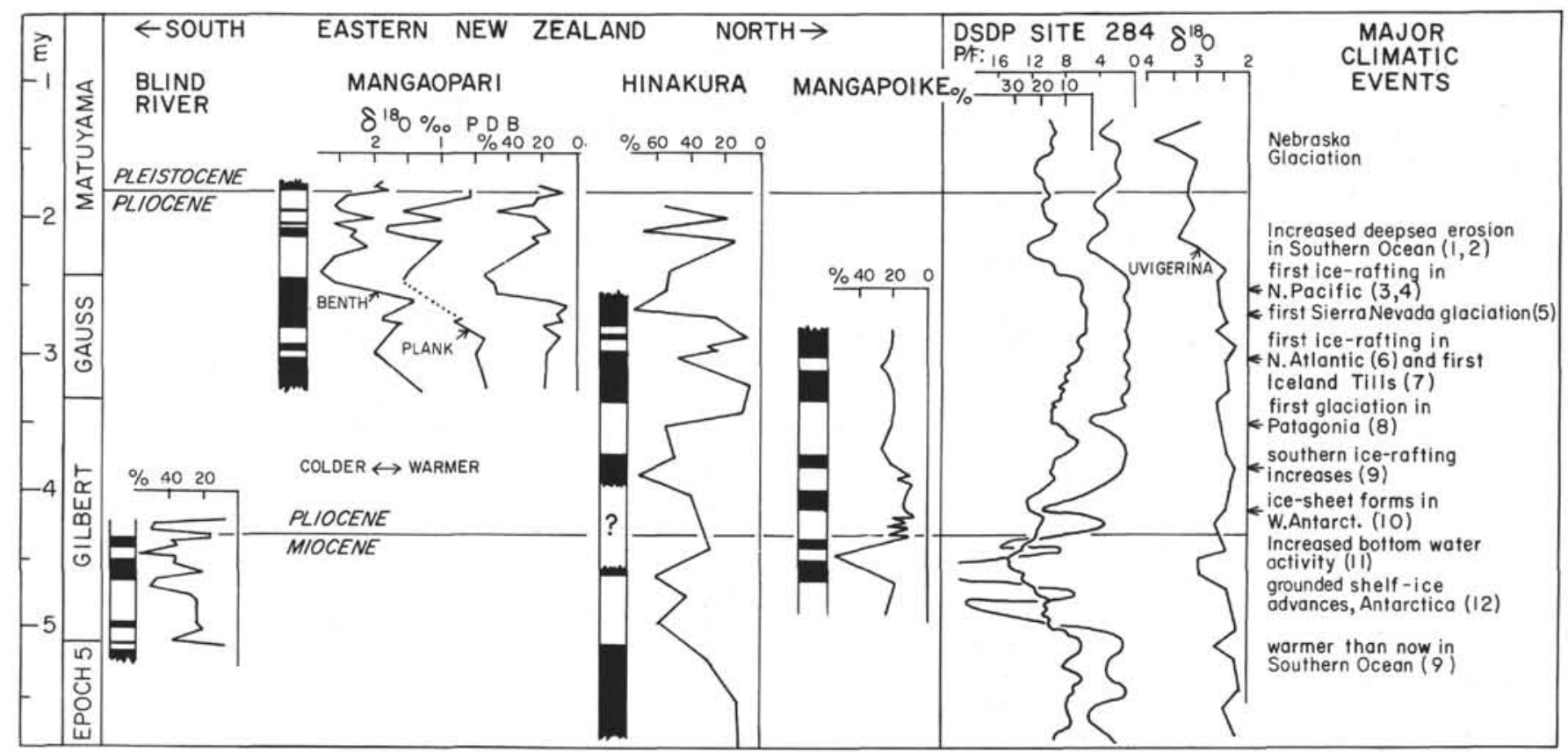

Figure 8. Paleomagnetic correlations and chronology of DSDP Site 284 and eastern New Zealand marine paleoclimatic sequences and chronology of selected late Cenozoic major climatic events in other regions. Paleomagnetic stratigraphy for the Mangaopari section after Kennett et al. (1971); for the Hinakura section after Lienert et al. (1972); and for the Mangapoike and Blind River sections after Kennett and Watkins (in press). Oxygen isotopic records for the Mangaopari section determined on benthonic and planktonic foraminifera is after Devereux et al. (1970) and for DSDP 284 based on the benthonic foraminifera Uvigerina is after Shackleton and Kennett (this volume). Percentage curves for each section represent frequency oscillations in the cool foraminifer Neogloboquadrina pachyderma. Increased percentages (toward the left) reflect colder intervals. Oscillations in the N. pachyderma/Globigerina falconensis ratio $(P / F)$ are also shown for Site 284. Paleomagnetic epochs shown at the left and chronology are after Cox (1966). Major climatic events recorded in other regions shown at right: 1=Watkins and Kennett, 1972; 2=Fillon, 1972; 3=Kent et al. 1971; 4=Echols, 1973; 5=Curray, 1966; 6=Berggren, 1972; 7=McDougall and Wensink, 1966; 8=Mercer, 1973; 9=Blank and Margolis, in press; 10=Mercer, 1972; 11=Kennett and Brunner, 1973;12=Hayes, Frakes, et al. 1973.

$m a$ indicate overall warmer conditions (Figure 8). The paleomagnetic dating of the eastern New Zealand sequences has enabled indirect dating of the paleoclimatic history at Site 284 (Figure 8). Water temperatures were relatively warm until $t=4.7 \mathrm{~m} . y$. , were significantly cooler between $t=4.7$ to $t=4.3$ m.y. (equivalent to the Kapitean Stage of New Zealand), were followed by a brief minor warming associated with the New Zealand Miocene-Pliocene boundary, followed by a resumption of cool conditions to $t=4.1 \mathrm{~m}$.y. This was followed by a prolonged warm interval to $t=2.6 \mathrm{~m} . \mathrm{y}$. (Opoitian Stage), which was interrupted by a brief cooling at about $t=3.4 \mathrm{~m} . \mathrm{y}$. Significantly cooler temperatures occurred from $t=2.6$ to $2.15 \mathrm{~m}$.y. and after this, temperatures fluctuated to the early to middle Pleistocene disconformity.

The substantial climatic fluctuations suggested by the planktonic foraminifera are strongly supported by the oxygen isotopic record described in a companion paper by Shackleton and Kennett, Chapter 20 (this volume). In particular, the severe climatic cooling indicated by faunal change during the latest Miocene Kapitean Stage is supported by distinct changes in the oxygen isotopes that reflect substantially greater dimensions of the Antarctic ice sheet than at the present day. The relatively minor cooling at about 3.4 m.y. is close to an oxygen isotopic change at $3.5 \mathrm{~m} . \mathrm{y}$. that reflects a lesser advance of the Antarctic ice sheet. Furthermore, the cool planktonic foraminiferal faunas of the late Pliocene Waipipian Stage commencing at about 2.6 m.y. are closely associated with marked change in the oxygen isotopes that record the accumulation of a substantial Northern Hemisphere ice sheet. This oxygen isotopic change was previously recorded by Devereux et al. (1970) from an eastern New Zealand section (Figure 8), where it is also closely associated with cool planktonic foraminiferal faunas. Thus, the oxygen isotopic paleotemperature record closely parallels that based on changes in the planktonic foraminifera, and strongly supports our paleoclimatic analyses.

The planktonic foraminiferal and oxygen isotopic paleotemperature curves are highly discordant with molluscan data. In both California (Addicott, 1969) and in New Zealand (Beu, in press), late Miocene molluscan fossils suggest warm-water conditions in marked contrast to planktonic foraminiferal faunas. Beu (in press) also considers that late Pliocene mollusca associated with the Waipipian Stage indicate warm-water conditions, which is also in conflict with our planktonic foraminiferal interpretations. Because of these conflicts, 
Beu (in press) states that planktonic foraminifera are not well enough known to be used as direct temperature indicators. We, however, believe that the validity of planktonic foraminiferal paleotemperatures is justified by the comparative simplicity of plankton ecologies, the consistent sympathetic variations among various planktonic foraminiferal parameters, and in particular, their consistent relationship with oxygen isotopic data. The planktonic foraminiferal and oxygen isotopic evidence from Site 284 supports previous suggestions of severe climatic conditions during both the latest Miocene Kapitean Stage, and the late Pliocene Waipipian Stage (Kennett, 1967; Devereux et al., 1970). This is in contrast to the conclusions of Beu (in press) who considers that workers in planktonic foraminifera must seek other explanations for changes in the planktonic foraminifera during Kapitean and Waipipian times.

Improved methods of correlation and dating of late Cenozoic rock sequences, especially as a result of paleomagnetic stratigraphy, have enabled paleoclimatic events to be correlated throughout the world, and the development of a fairly consistent pattern of global late Cenozoic climatic history. The more conspicuous, and even some more minor climatic events recorded in the Site 284 and New Zealand marine sequences have counterparts in other parts of the world (Figure 8).

The late Tongaporutuan Stage is correlated with Epoch 5 and the early part of the Gilbert Reversed Paleomagnetic Epoch (Figure 8). Relatively warm conditions during at least part of this interval at Site 284 compare with conditions in the Southern Ocean that Blank and Margolis (in press) consider to be warmer than the present day, and with an interval of reduced ice-rafted sediments (Kennett and Brunner, 1973). The oxygen isotopic record at Site 284, however, demonstrates the presence within this interval of a substantial Antarctic ice sheet, although this was probably less stable than during later periods (Shackleton and Kennett, Chapter 20, this volume).

The severe climatic cooling that occurred approximately during the Gilbert C Event $(t=4.7$ to $t=4.3$ m.y.-Kapitean Stage) is marked by both substantial changes in planktonic foraminiferal faunas and in oxygan isotopic composition. This indicates a major expa.ısion of the Antarctic ice sheet to a size substantially greater than at the present day (Shackleton and Kennett, this volume), a conclusion that is supported by results of deep-sea drilling (Leg 28) in the Ross Sea (Hays, Frakes, et al., 1973), and by the first appearance of ice-rafted quartz associated with Gilbert C Event, in Eltanin Core 34-5 (from northern Antarctic waters (Kennett and Brunner, 1973). Possibly synchronous late Miocene cooling is inferred from changes in planktonic foraminiferal faunas, in California (Ingle, 1967), and in north Pacific DSDP cores (Ingle, 1973), and from high calcium carbonate content below the Cochiti Event in equatorial Pacific cores (Hays et al., 1969).

The severe cooling occurring near the base of the Opoitian Stage (near the middle of the Gilbert Epoch, $t$ $=4.2$ to $4.1 \mathrm{~m} . \mathrm{y}$.) coincides with a cooling episode in southern Argentina that Mercer (1972) considered to correspond to the development of the West Antarctic ice sheet. Shackleton and Kennett (this volume) consider that the west Antarctic ice sheet formed at an earlier date, but the suggested climatic cooling at the middle of the Gilbert Epoch is supported by a substantial increase in ice rafting in the Southern Ocean (Blank and Margolis, in press), and increase in bottom-water activity in the northern Antarctic probably resulting from a further critical development of Antarctic glaciation (Kennett and Brunner, 1973).

The minor cooling recorded by planktonic foraminifera and oxygen isotopic changes about 3.5 to 3.4 m.y. during the late Gilbert Epoch (middle Opoitian Stage) corresponds with the time of the first glaciation in Patagonia (Mercer, 1973). This was followed by one of the most prolonged warm late Cenozoic episodes occurring during the Gauss Normal Epoch $(t=3.32$ to 2.43 m.y.- - late Opoitian Stage). During this time there were possibly no glaciations in Patagonia (Mercer, 1973) but the first conspicuous evidence of climatic deterioration appeared in the Northern Hemisphere. Berggren (1972) noted a minor influx of ice rafted debris approximately $3 \mathrm{~m} . \mathrm{y}$. ago, and later a major influx culminating about 2.6 m.y., near the end of the Gauss. In Iceland, the first tills accumulated 3 m.y. ago (McDougall and Wensink, 1966). According to Berggren (1972), these reflect the initiation of climatic cooling in the Northern Hemisphere that shortly afterwards led to continental glaciation. The first glaciation developed in the Sierra Nevada Mountains of the western United States is dated at 2.7 m.y. ago (Curray, 1966), and the first ice rafting in the north Pacific area at about 2.5 to 2.6 m.y. (Kent et al., 1971; Echols, 1973).

The maximum of late Pliocene cooling occurred approximately 2.6 m.y. ago near the end of the Gauss Epoch and extended into the early Matuyama Reversed Epoch. At this time a major and rapid oxygen isotopic change recorded at Site 284 (Shackleton and Kennett, this volume) and in eastern New Zealand (Devereux et al., 1970; Kennett et al., 1971) at the base of the Waipipian Stage clearly records the first substantial buildup of continental ice in the Northern Hemisphere (Figure 8). This event coincides with the first major influx of icerafted sediments to the north Atlantic (Berggren, 1972). Also at about this time deep-sea erosion commenced over wide areas in the Southern Ocean (Watkins and Kennett, 1972; Fillon, 1972) which almost certainly resulted from glacially intensified bottom-water activity. During the late Gauss, an increase in carbonate content in equatorial Pacific cores also probably resulted from climatic cooling (Hays et al., 1969).

\section{CONCLUSIONS}

1. DSDP Site 284 , in temperate waters near New Zealand, is a late Miocene (6 m.y.) to Recent sequence consisting of 208 meters of relatively shallow-water calcareous ooze. The biostratigraphy permitted dating by reference to paleomagnetically dated marine sections in New Zealand. Much of the Pleistocene is missing in disconformity.

2. Planktonic foraminiferal populations have been counted at intervals of approximately 1.5 meters 
throughout to determine changes in frequencies of species, assemblages diversity, and ratios between certain species.

3. Frequency oscillations of the cool-water foraminifer Neogloboquadrina pachyderma is the most useful criterion for determining paleoclimatic history in the temperate South Pacific. Other useful criteria are frequency oscillations of Globigerina woodi which is essentially opposite those of $N$. pachyderma; and changes in the ratios of $N$. pachyderma/Globigerina falconensis and $G$. bulloides $/ G$. falconensis. Frequency oscillations in most other species are not obviously related to paleotemperature change.

4. Coiling of $N$. pachyderma did not adopt its presentday pattern until the early Pliocene, or possibly later and cannot be used for paleotemperature analysis of the late Miocene or early Pliocene faunas.

5. A relatively detailed paleoclimatic record for the late Miocene to early Pleistocene has been established for the Site 284 sequence. The salient features are severe cooling episodes from 4.7 to $4.1 \mathrm{~m} . \mathrm{y}$. associated with the New Zealand Kapitean and earliest Opoitian Stages, and in the late Pliocene from 2.6 to 2.15 m.y. associated with the Waipipian Stage. Prolonged relative warmth, interrupted by only a single brief cool interval, occurred during the middle Pliocene from 4.1 to $2.6 \mathrm{~m} . \mathrm{y}$.

6 . The faunally determined paleotemperature changes coincide with changes in oxygen isotopic composition of water considered by Shackleton and Kennett (this volume) to represent significant changes in ice volume on Antarctica in the late Miocene and within the Northern Hemisphere in the late Pliocene and Pleistocene.

7. Paleoclimatic interpretations using planktonic foraminifera are discordant with those based on molluses for the late Miocene of New Zealand and California, and the late Pliocene of New Zealand. The molluscs indicate warm-water conditions at these times.

The planktonic foraminiferal interpretations are supported by oxygen isotopic changes, by paleoglacial history in both hemispheres, and by glacio-eustatic changes.

\section{ACKNOWLEDGMENTS}

We appreciate diverse technical assistance provided by Ms. Nancy Healy and Ms. Annette Doherty and photographic assistance by Mr. Cassidy. The scanning electron microscope was operated by D. Scales. This work was supported by U.S. National Science Foundation Grants GA-35252 (Oceanography Division) and GV-28305 (Office of Polar Programs). P. Vella acknowledges the assistance of a Fulbright-Hays Travel Grant that enabled him to carry out this study at the Graduate School of Oceanography, University of Rhode Island.

\section{REFERENCES}

Addicott, W. O., 1969. Tertiary climatic change in the marginal northeastern Pacific Ocean: Science, v. 165, p. 583-6.

Bandy, O. L., Casey, R. E., and Wright, R. C., 1971. Late Neogene planktonic zonation, magnetic reversals, and radiometric dates, Antarctic to the tropics: Am. Geophys. Union Antarctic Res. Ser., v. 15, p. 1-26.
Bé, A. W. H., 1969. Planktonic foraminifera. In Distribution of selected groups of marine invertebrates in waters south of $35^{\circ} \mathrm{S}$ latitude. Antarctic Map Folio Series, Folio II: Washington (American Geographical Society), p. 9-12.

Berger, W. H. and Parker, F. L., 1970. Diversity of planktonic foraminifera in deep-sea sediments: Science, v. 168, p. 13451347.

Berggren, W. A., 1972. Late Pliocene-Pleistocene glaciation. In Laughton, A. S., Berggren, W. A. et al., Initial Reports of the Deep-Sea Drilling Project, Volume 12: Washington (U.S. Government Printing Office), p. 953-964.

Berggren, W. A., Phillips, J. D., Bertels, A., and Wall, D., 1967. Late Pliocene-Pleistocene stratigraphy in deep-sea cores from the south-central North Atlantic: Nature, v. 216 , p. 253-254.

Beu, A. G., in press. Molluscan evidence of warm sea temperature in New Zealand during Kapitean (late Miocene) and Waipipian (middle Pliocene) time: New Zealand Journal Geol. Geophys.

Blank, R. G. and Margolis, S. V., in press. Paleoceanography of the South-Eastern Indian Ocean and paleoglacial history of Antarctica as revealed by Late Cenozoic deep-sea sediments: Geol. Soc. Am. Bull.

Cox, A., 1969. Geomagnetic Reversals: Science, v. 163, p. $237-$ 245.

Curray, R. R., 1966, Glaciation about 3,000,000 years ago in the Sierra Nevada: Science, v. 154, p. 770-771.

Deacon, G. E. R., 1937. Hydrology of the Southern Ocean: "Discovery," Rept. 15, p. 1-124.

Devereux, I., Hendy, C. M., and Vella, P., 1970. Pliocene and early Pleistocene sea temperature fluctuations, Mangaopari Stream, New Zealand: Earth Planet. Sci. Lett., v. 8, p. 163168.

Echols, R. J., 1973. Foraminifera, Leg 19, Deep-Sea Drilling Project. In Creager, J. S., Scholl, D. W., et al., Initial Reports of the Deep-Sea Drilling Project, Volume 19: Washington: (U.S. Government Printing Office), p. 721735.

Echols, R. J., and Kennett, J. P., 1973. Distribution of foraminifera in the surface sediments. In Bushnell, V. (Ed.), Marine sediments of the Southern Oceans, Antarctic Map Folio Series 17: Washington (American Geographical Society).

Fillon, R. H., 1972. Evidence from the Ross Sea for widespread submarine erosion: Nature Phys. Sci., v. 23, p. 4042.

Fleming, C. A., 1944. Molluscan evidence of Pliocene climatic change in New Zealand: Roy. Soc. New Zealand Trans., v. 74 , p. $207-220$.

1962. New Zealand biogeography: a paleontologist's approach: Tuatara, v. 10, p. 53-108.

Garner, D. M., 1954. Sea surface temperature in the southwest Pacific Ocean from 1949 to 1952: New Zealand J. Sci. Tech. B 36, p. 285-303.

Hayes, D. E., Frakes, L. A., Wall, R. E., Barrett, P. J., Ford, A. B., Kemp, E. M., Piper, J. W., McCollum, D. W., Kaneps, A., Webb, P. N., Burns, D. A., and Chen, P.-H., 1973. Leg 28 Deep-Sea Drilling in the Southern Ocean: Geotimes, v. 18, p. 19-24.

Hays, J. D., Saito, T., Opdyke, N. D., and Burckle, L. H., 1969. Pliocene-Pleistocene sediments of the Equatorial Pacific: Their paleomagnetic, biostratigraphic and climatic record: Geol. Soc. Am. Bull., v. 80, p. 1481-1514.

Ingle, J. C., Jr., 1967. Foraminiferal biofacies variation and the Mio-Pliocene boundary in southern California: Bull. Am. Paleontol., v. 52, p. 236.

1973. Neogene foraminifera from the northeastern Pacific Ocean, Leg 18, Deep-Sea Drilling Project. In Kulm, L. D., von Huence, R., et al., Initial Reports of the Deep- 
Sea Drilling Project, Volume 18: Washington (U.S. Government Printing Office), p. 517-568.

Jenkins, D. G., 1967. Recent distribution, origin, and coiling ratio changes in Globorotalia pachyderma (Ehrenberg): Micropaleontology, v. 13, p. 195-203.

1968. Variations in the numbers of species and subspecies of planktonic foraminifera as an indicator of New Zealand Cenozoic paleotemperatures: Paleogeogr., Paleoclimatol., Paleoecol. v. 5, p. 309-313.

Kennett, J. P., 1967. Recognition and correlation of the Kapitean Stage (Upper Miocene, New Zealand): New Zealand J. Geol. Geophys., v. 10, p. 1051-1063.

1970. Pleistocene paleoclimates and foraminiferal biostratigraphy in subantarctic deep-sea cores: Deep-Sea Res., v. 17, p. 125-140.

1973. Middle and late Cenozoic planktonic foraminiferal biostratigraphy of the southwest Pacific-DSDP Leg 21. In Burns, R. E. and Andrews, J. E., Initial Reports of the Deep-Sea Drilling Project, Volume 21: Washington, (U.S. Government Printing Office), p. 575-640.

Kennett, J. P. and Brunner, C. A., 1973. Antarctic late Cenozoic glaciation: Evidence for initiation of ice rafting and inferred increased bottom water activity: Geol. Soc. Am. Bull., v. 84, p. 2043-2052.

Kennett, J. P. and Watkins, N. D., in press. Late MioceneEarly Pliocene paleomagnetic stratigraphy, paleoclimatology and biostratigraphy in New Zealand: Geol. Soc. Am. Bull.

Kennett, J. P., Watkins, N. D., and Vella, P., 1971. Paleomagnetic chronology of Pliocene-early Pleistocene climates and the Plio-Pleistocene boundary in New Zealand: Science, v. 171, p. 276-279.

Kent, D., Opdyke, N. D., and Ewing, M., 1971. Climate change in the North Pacific using ice-rafted detritus as a climate indicator: Geol. Soc. Am. Bull., v. 82, p. 2741-2754.

Lienert, B. R., Christoffel, D. A., and Vella, P., 1972. Geomagnetic dates on a New Zealand upper MiocenePliocene section: Earth Planet. Sci. Lett., v. 16, p. 195-199.

Margolis, S. V. and Kennett, J. P., 1971. Cenozoic paleoglacial history of Antarctica recorded in subantarctic deep-sea cores: Am. J. Sci. v. 271, p. 1-36.

McDougall, I., and Wensink, H., 1966. Paleomagnetism and geochronology of the Pliocene-Pleistocene lavas in Iceland: Earth Planet. Sci. Lett., v. 1, p. 232-236.

Mercer, J. H., 1972. Cainozoic temperature trends in the southern hemisphere: Antarctic and Andean glacial evidence: Paleoecology of Africa: Sci. Comm. Antarctic Res. Conf. Quaternary Studies, no. 8.

1973. Southern Argentina: Glacial events between 4 m.y. and I m.y. ago during the Gilbert, Gauss and Matuyama geomagnetic polarity epochs: Cong. Intern. Union Quaternary Res. 9th p. 255, 256 (Abstracts).

Phillips, J. D., Berggren, W. A., Bertels, A., and Wall, D., 1968. Paleomagnetic stratigraphy and micropaleontology of three deep-sea cores from the central North Atlantic Ocean: Earth Planet. Sci. Lett., v. 4, p. 118.

Vella, P. and Nicol, E. R., 1972. Chlamys delicatula and the Hautawan Stage (Letter): New Zealand J. Geol. Geophys., v. 13 , p. $873-876$.

Watkins, N. D. and Kennett, J. P., 1972. Regional Sedimentary disconformities and upper Cenozoic changes in bottom water velocities between Australasia and Antarctica: Am. Geophys. Union Antarctic Res. Ser., v. 19, p. 273-293. 



\section{PLATE 1}

Figures 1-4 Globigerina bulloides d'Orbigny; Sample 284-1-5, $40 \mathrm{~cm}$.

1. Umbilical view; $\times 118$.

2. Umbilical view; $\times 149$.

3. Umbilical view; $\times 134$.

4. Spiral view; $\times 144$.

Figure 5 Globigerina falconensis Blow; Sample 284-1-1, 25 $\mathrm{cm}$; umbilical view; $\times 155$.

Figures 6-8 Globigerina bulloides $\times$ Globigerina falconensis; Sample 284-1-2, $25 \mathrm{~cm}$.

6. Umbilical view; $\times 151$.

7. Umbilical view; $\times 144$.

8. Umbilical view; $\times 148$.

Figures 9-12 Globigerina woodi Jenkins; Sample 284A-3-2, 40 $\mathrm{cm}$.

9. Umbilical view; $\times 217$.

10. Umbilical view; $\times 162$.

11. Umbilical view; $\times 192$.

12. Spiral view; $\times 197$.

Figures 13, 14 Globigerina apertura Cushman; Sample 284-7-3, 40 $\mathrm{cm}$.

13. Spiral view; $\times 162$.

14. Umbilical view; $\times 142$.

Figures 15, 16 Globigerina decoraperta Takayanagi and Saito; Sample 284-14-1, $40 \mathrm{~cm}$.

15. Side view; $\times 185$.

16. Umbilical view; $\times 231$. 


\section{PLATE 1}
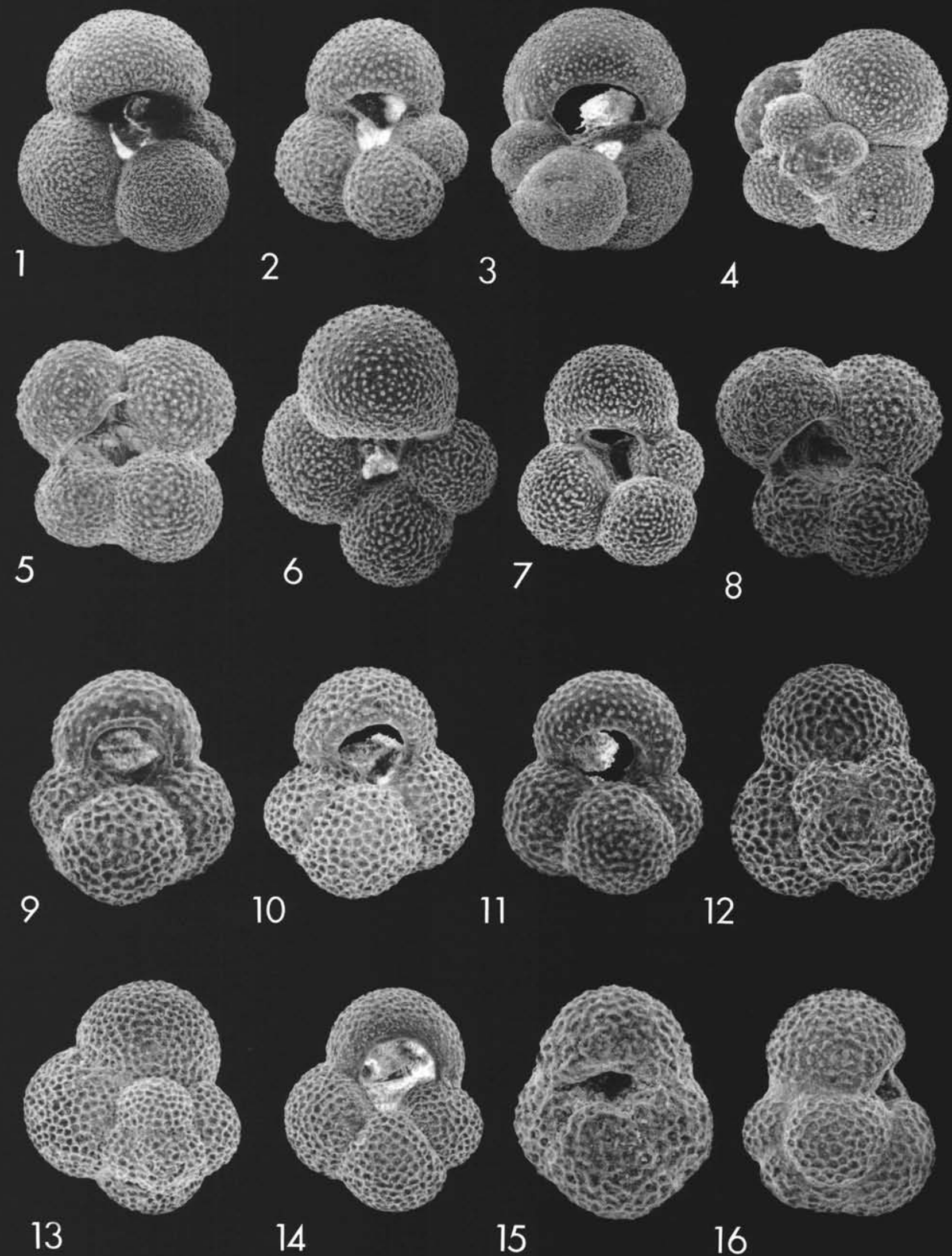


\section{PLATE 2}

Figure 1 Globigerina eamsi Blow; Sample 284-26-5, $40 \mathrm{~cm}$; side view; $\times 150$.

Figures 2-6 Globigerina quinqueloba Natland; Sample 284-1-2, $25 \mathrm{~cm}$.

2. Umbilical view; $\times 198$.

3. Umbilical view; $\times 234$.

4. Side view; $\times 272$.

5. Side view; $\times 209$.

6. Side view; $\times 221$.

Figure 7 Globigerina digitata Brady; Sample 284-1-5, $40 \mathrm{~cm}$; side view; $\times 190$.

Figures 8-10 Neogloboquadrina pachyderma (Ehrenberg), rightcoiling form from late Pleistocene; Sample 284-1$1,25 \mathrm{~cm}$.

8. Spiral view; $\times 190$.

9. Umbilical view; $\times 179$.

10. Side view; $\times 168$.

Figures 11-15 Neogloboquadrina pachyderma (Ehrenberg), leftcoiling form from late Pleistocene; Sample 284A$1-6,84 \mathrm{~cm}$.

11. Umbilical view; $\times 183$.

12. Umbilical view; $\times 192$.

13. Umbilical view; $\times 228$.

14. Umbilical view; $\times 231$.

15. Spiral view; $\times 197$.

Figure $16 \quad$ Neogloboquadrina dutertrei (d'Orbigny); Sample 284-1-5, $40 \mathrm{~cm}$; umbilical view; $\times 95$. 


\section{PLATE 2}
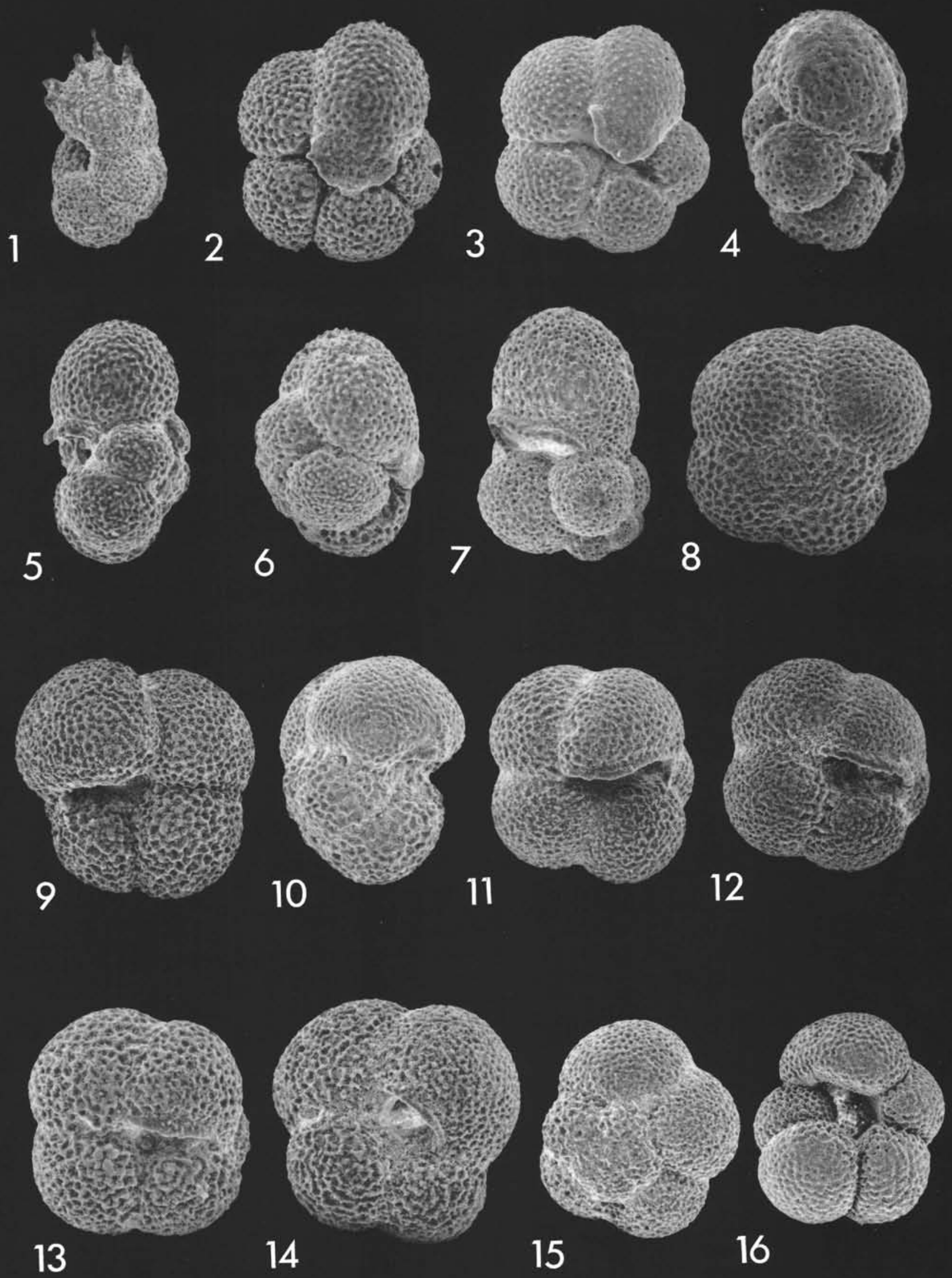


\section{PLATE 3}

Figure $1 \quad$ Neogloboquadrina dutertrei (d'Orbigny); Sample 284-1-5, $40 \mathrm{~cm}$; umbilical view; $\times 110$.

Figures 2-6 Neogloboquadrina pachyderma (Ehrenberg), leftcoiling form.

2. Sample 284-17-6, $40 \mathrm{~cm}$; late Miocene form; umbilical view; $\times 209$.

3. Umbilical view; $\times 221$.

4. Sample $284 \mathrm{~A}-1-6,84 \mathrm{~cm}$; spiral view, late Pleistocene form; $\times 189$.

5. Sample 284-17-6, $40 \mathrm{~cm}$; late Miocene form; umbilical view; $\times 210$.

6. Umbilical view; $\times 212$.

Figures 7-11 Globorotalia hirsuta d'Orbigny; Sample 284-1-1, 25 $\mathrm{cm}$.

7. Umbilical view; $\times 56$.

8. Umbilical view; $\times 84$.

9. Spiral view; $\times 69$.

10. Side view; $\times 70$.

11. Side view; $\times 94$.

Figures 12-14 Globorotalia crassula Cushman and Stewart; Sample $284-3-5,40 \mathrm{~cm}$.

12. Umbilical view; $\times 116$.

13. Spiral view; $\times 110$.

14. Side view; $\times 96$.

Figures 15, 16 Globorotalia truncatulinoides (d'Orbigny); Sample 284-1-1, $25 \mathrm{~cm}$.

15. Side view; $\times 78$.

16. Spiral view; $\times 105$. 
PLATE 3
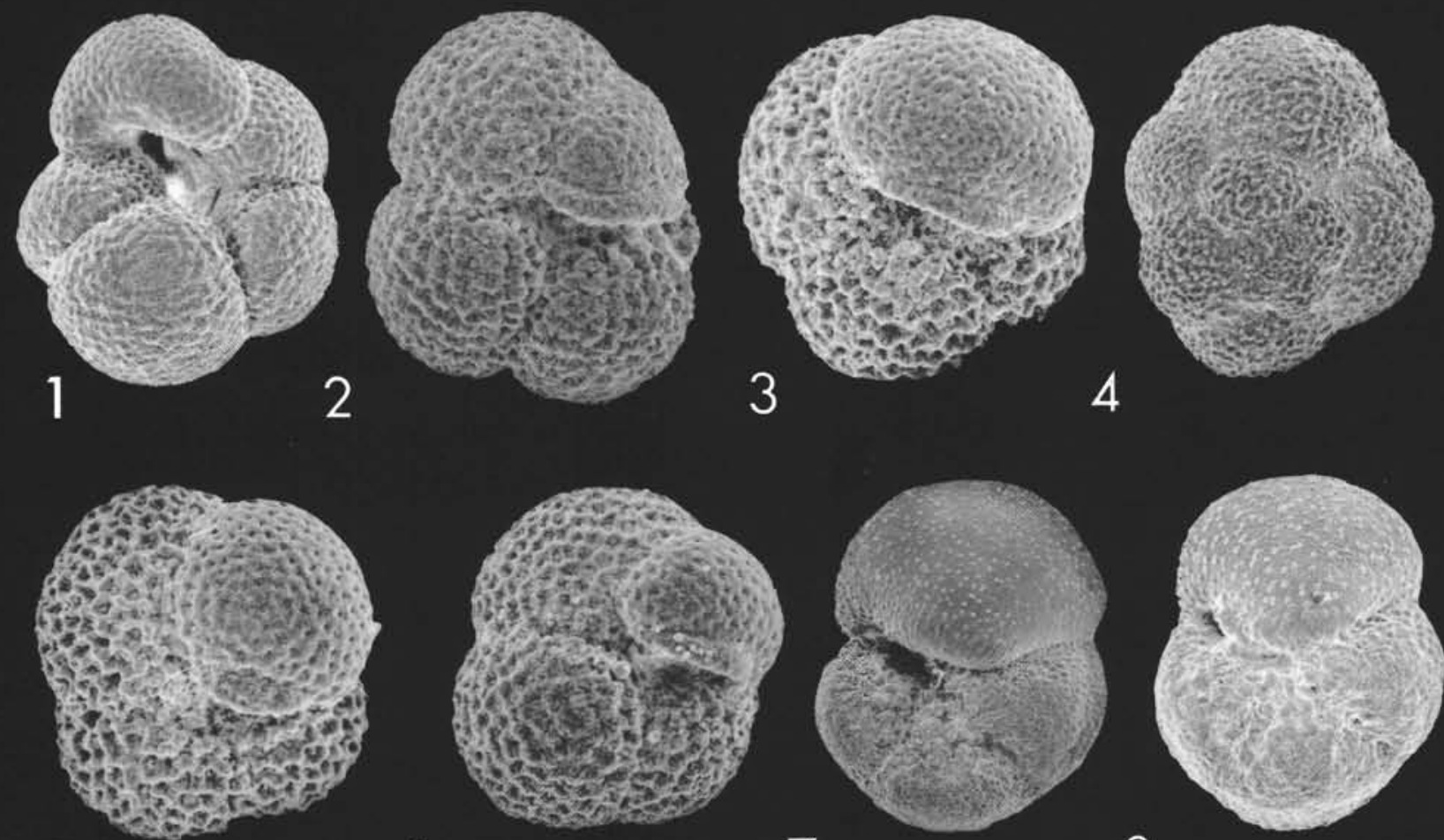

5

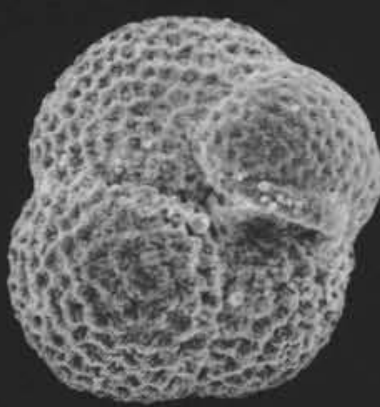

6

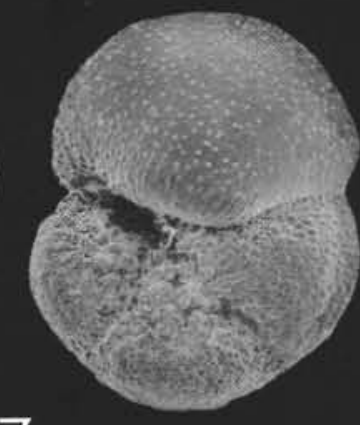

7
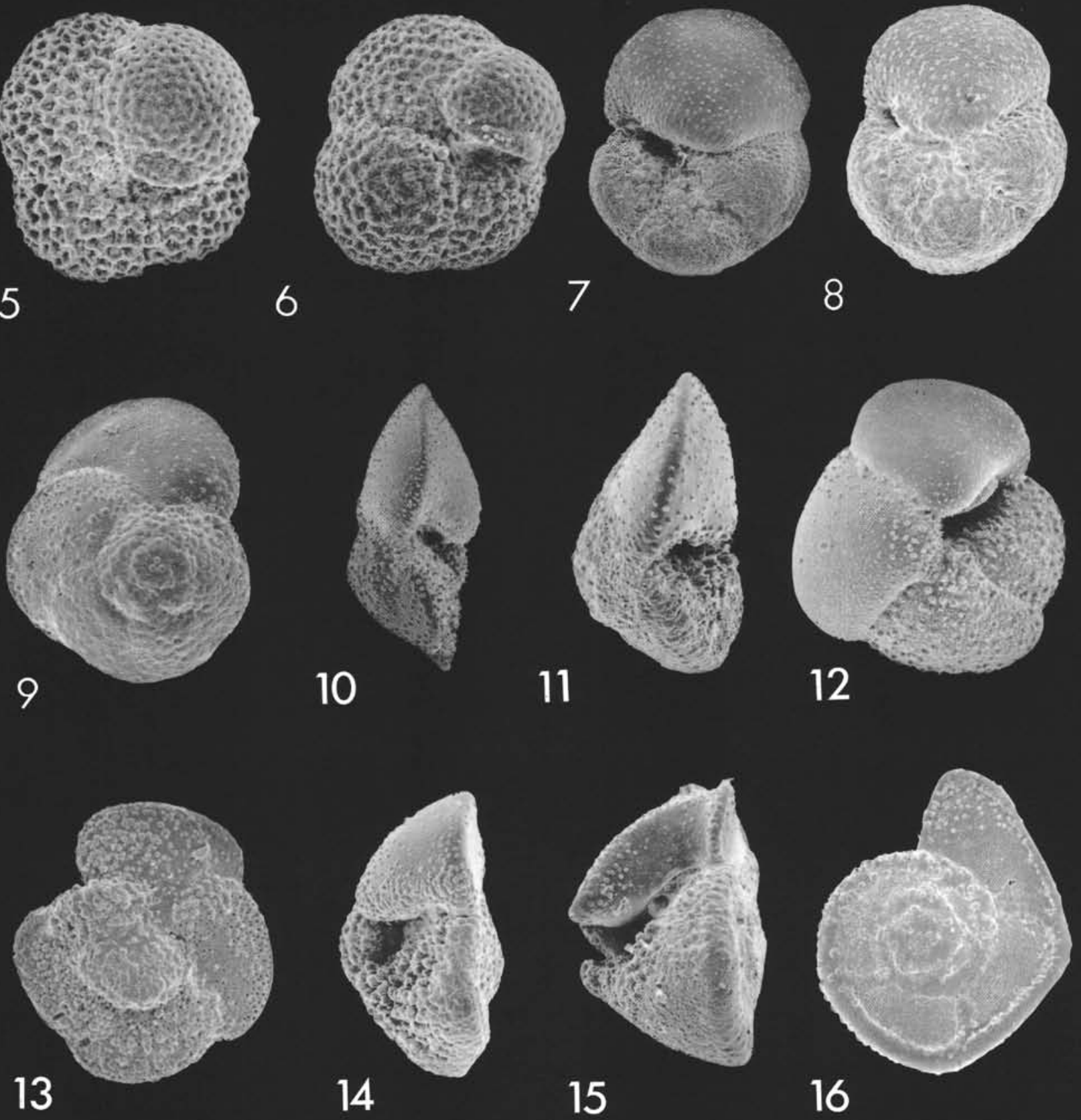


\section{PLATE 4}

Figure $1 \quad$ Globorotalia truncatulinoides (d'Orbigny); Sample 284-1-1, $25 \mathrm{~cm}$; umbilical view; $\times 95$.

Figures 2-4 Globorotalia scitula (Brady); Sample 284-1-5, 40 $\mathrm{cm}$.

2. Umbilical view; $\times 135$.

3. Umbilical view; $\times 116$.

4. Side view; $\times 131$.

Figures 5-10 Globorotalia crassaformis Galloway and Wissler.

5. Umbilical view; $\times 107$.

6. Sample 284-10-4, $40 \mathrm{~cm}$; umbilical view; keeled form; $\times 105$.

7. Spiral view, keeled form; $\times 133$.

8. Sample $284-1-5,40 \mathrm{~cm} ; \times 107$.

9. Spiral view; $\times 124$.

10. Umbilical view; $\times 131$.

Figures 11-14 Globorotalia cf. puncticulata (d'Orbigny); Sample 284-11-4, $128 \mathrm{~cm}$.

11. Side view; $\times 111$.

12. Spiral view; $\times 101$.

13. Side view; $\times 106$.

14. Umbilical view; $\times 123$.

Figures 15, 16 Globorotalia $\mathrm{cf}$. conomiozea Kennett.

15. Side view; $\times 97$.

16. Spiral view; $\times 91$. 

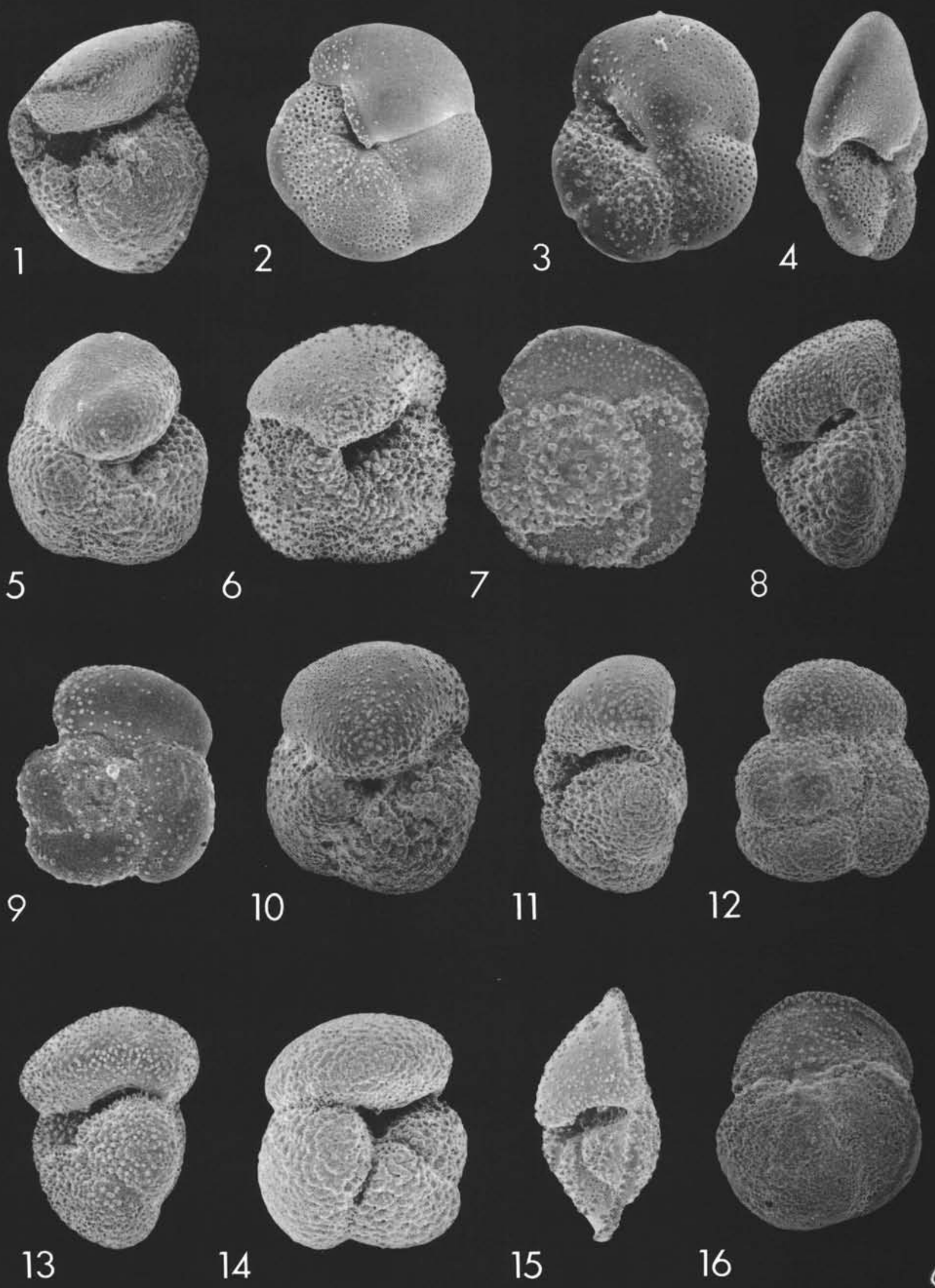


\section{PLATE 5}

Figure $1 \quad$ Globorotalia cf. conomiozea Kennett; Sample 284$11-14,128 \mathrm{~cm}$; side view; $\times 64$.

Figure 2 Globorotalia cf. miozea Finlay; Sample 284-22-2, $40 \mathrm{~cm}$; side view; $\times 152$.

Figure 3 Globorotalia cf. conomiozea Kennett; Sample 284$11-4,128 \mathrm{~cm}$; side view; $\times 71$.

Figures 4-8 Globorotalia cibaoensis Bermudez; Sample 284-15$4,40 \mathrm{~cm}$.

4. Umbilical view; $\times 126$.

5. Umbilical view; $\times 129$.

6. Side view; $\times 131$.

7. Side view; $\times 117$.

8. Spiral view; $\times 131$.

Figures 9-16 Globorotalia inflata (d'Orbigny)

9. Sample 284-6-1, $40 \mathrm{~cm}$; umbilical view; Pliocene form; $\times 107$.

10. Side view; Pliocene form; $\times 85$.

11. Sample $284-1-1,25 \mathrm{~cm}$; umbilical view; late Pleistocene form; $\times 106$.

12. Side view; late Pleistocene form; $\times 111$.

13. Umbilical view; late Pleistocene form; $\times 113$.

14. Umbilical view; late Pleistocene form; $\times 78$.

15. Side view; late Pleistocene form; $\times 92$.

16. Spiral view, late Pleistocene form; $\times 115$. 


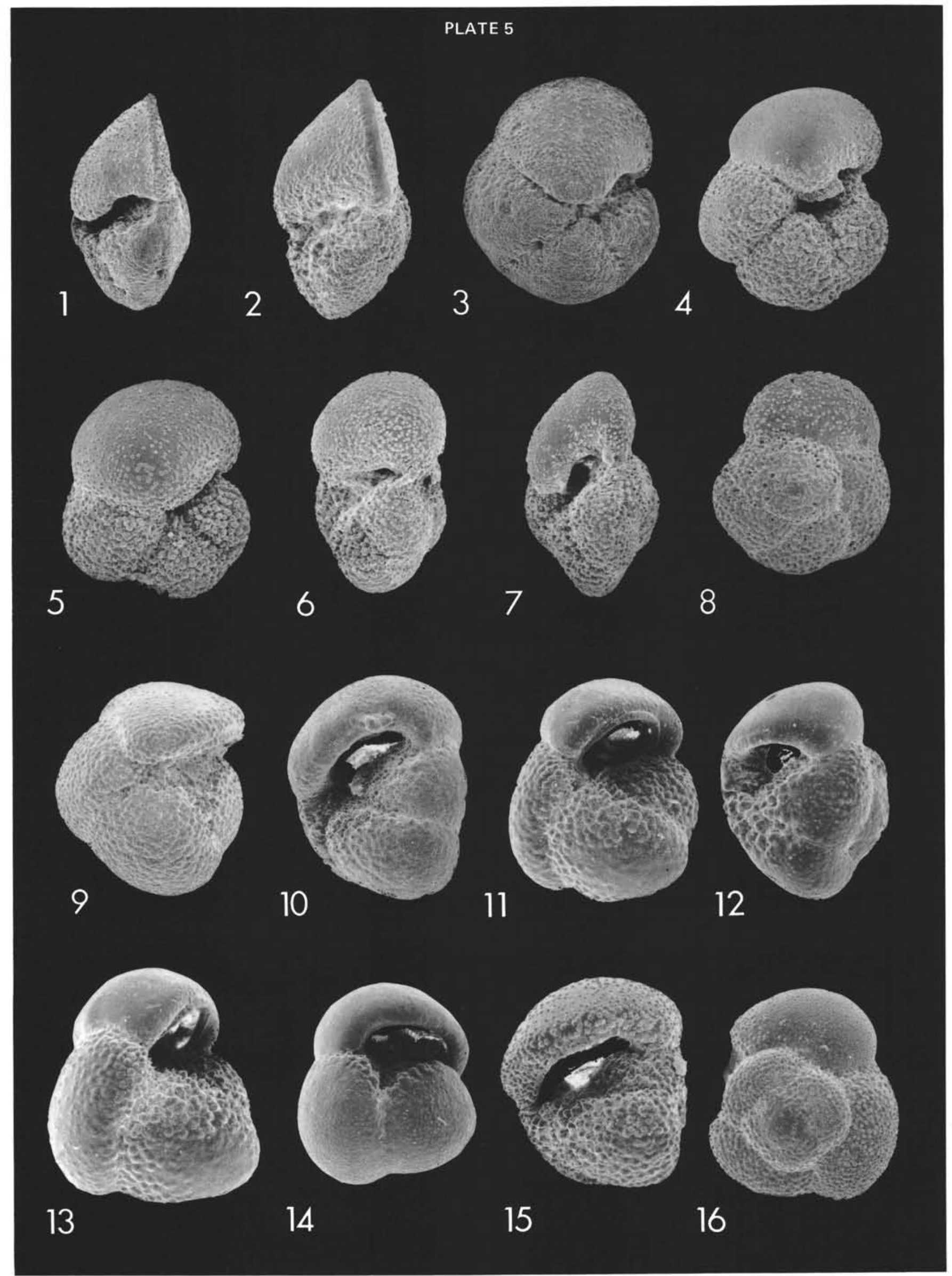




\section{PLATE 6}

Figures 1, 2 Globorotalia inflata (d'Orbigny); Sample 284-6-1, $40 \mathrm{~cm}$.

1. Umbilical view; Pliocene form; $\times 107$.

2. Umbilical view; Pliocene form; $\times 100$.

Figures 3-6 Globorotalia puncticulata (d'Orbigny); Sample 284-11-4, $128 \mathrm{~cm}$.

3. Oblique umbilical view; $\times 128$.

4. Spiral view; $\times 163$.

5. Side view; $\times 165$.

6. Umbilical view; $\times 146$.

Figure 7-15 Globorotalia puncticulata $\times$ Globorotalia conomiozea; Sample 284-15-3, $128 \mathrm{~cm}$.
7. Umbilical view; $\times 107$.
8. Side view; $\times 112$.
9. Side view; $\times 116$.
10. Side view; $\times 155$.
11. Spiral view; $\times 116$.
12. Spiral view; $\times 133$.
13. Umbilical view; $\times 93$.
14. Side view; $\times 107$.
15. Umbilical view; $\times 89$.

Figure $16 \quad$ Globorotalia conomiozea Kennett; Sample 284-16$4,40 \mathrm{~cm}$; umbilical view; $\times 98$. 
PLATE 6
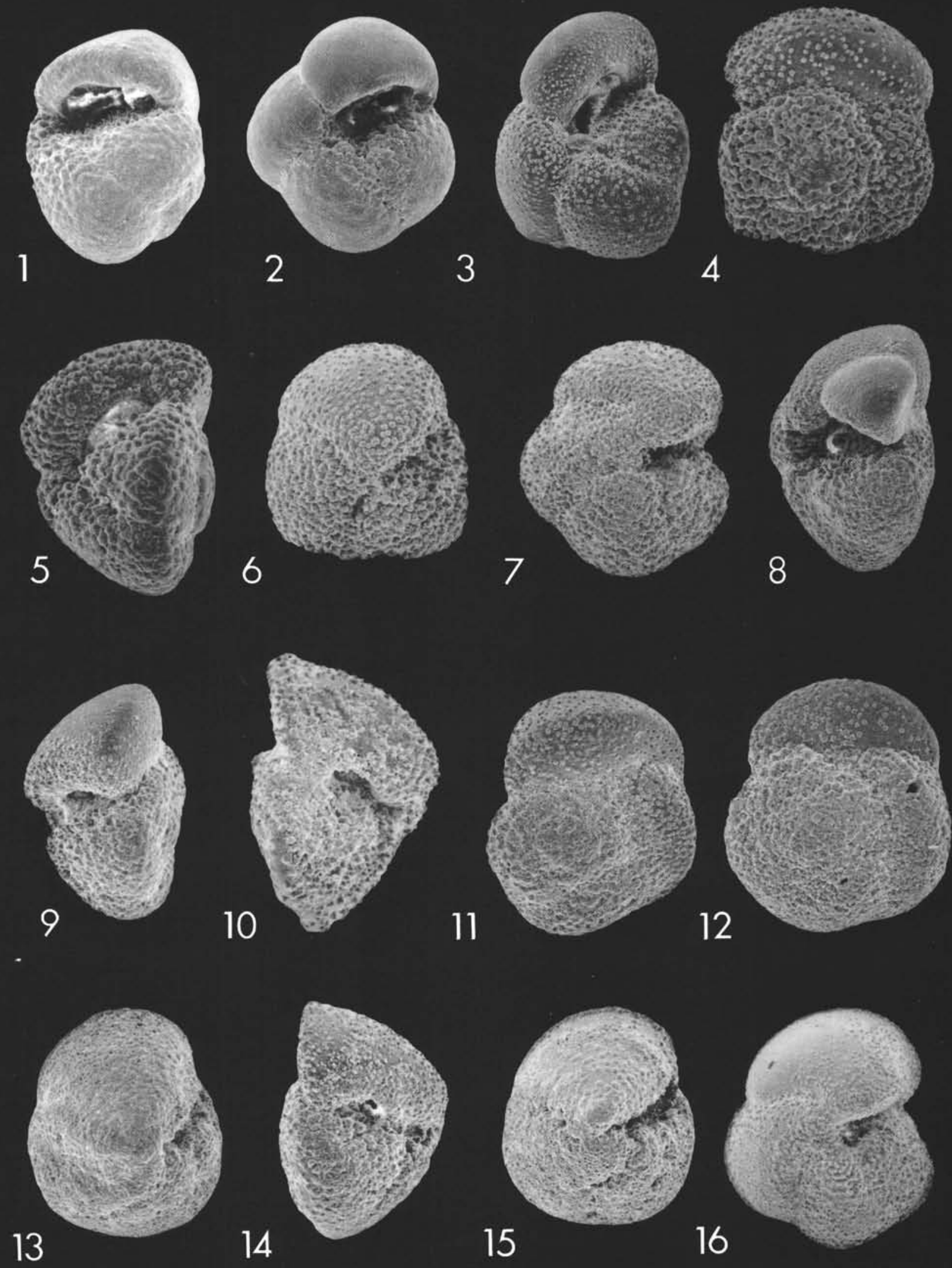


\section{PLATE 7}

Figures 1-5 Globorotalia conomiozea Kennett; Sample 284-16$4,40 \mathrm{~cm}$.

1. Side view; $\times 93$.

2. Side view; $\times 82$.

3. Spiral view; $\times 104$.

4. Umbilical view; $\times 93$.

5. Spiral view; $\times 102$.

Figures 6-8 Globorotalia miozea conoidea Walters; Sample 284-18-6, $40 \mathrm{~cm}$.

6. Side view; $\times 91$.

7. Umbilical view; $\times 97$.

8. Spiral view; $\times 91$.

Figures 9-11 Globorotalia cf. miozea Finlay; Sample 284-22-2, $40 \mathrm{~cm}$.

9. Umbilical view; $\times 105$.

10. Umbilical view; $\times 114$.

11. Spiral view; $\times 151$

Figure 12 Globigerinoides ruber (d'Orbigny); Sample 284-1-5, $40 \mathrm{~cm}$; side view; $\times 125$.

Figure 13 Globigerinoides sacculifer (Brady); Sample 284-9-5, $40 \mathrm{~cm}$; umbilical view; $\times 138$.

Figure 14 Globigerinoides obliquus Bolli; Sample 284-9-5, 40 $\mathrm{cm}$; side view; $\times 148$.

Figure 15 Hastigerina aequilateralis Brady; Sample 284-1-1, $25 \mathrm{~cm}$; umbilical view; $\times 137$.

Figure 16 Orbulina universa d'Orbigny; Sample 284-1-5, 40 $\mathrm{cm} ; \times 93$. 

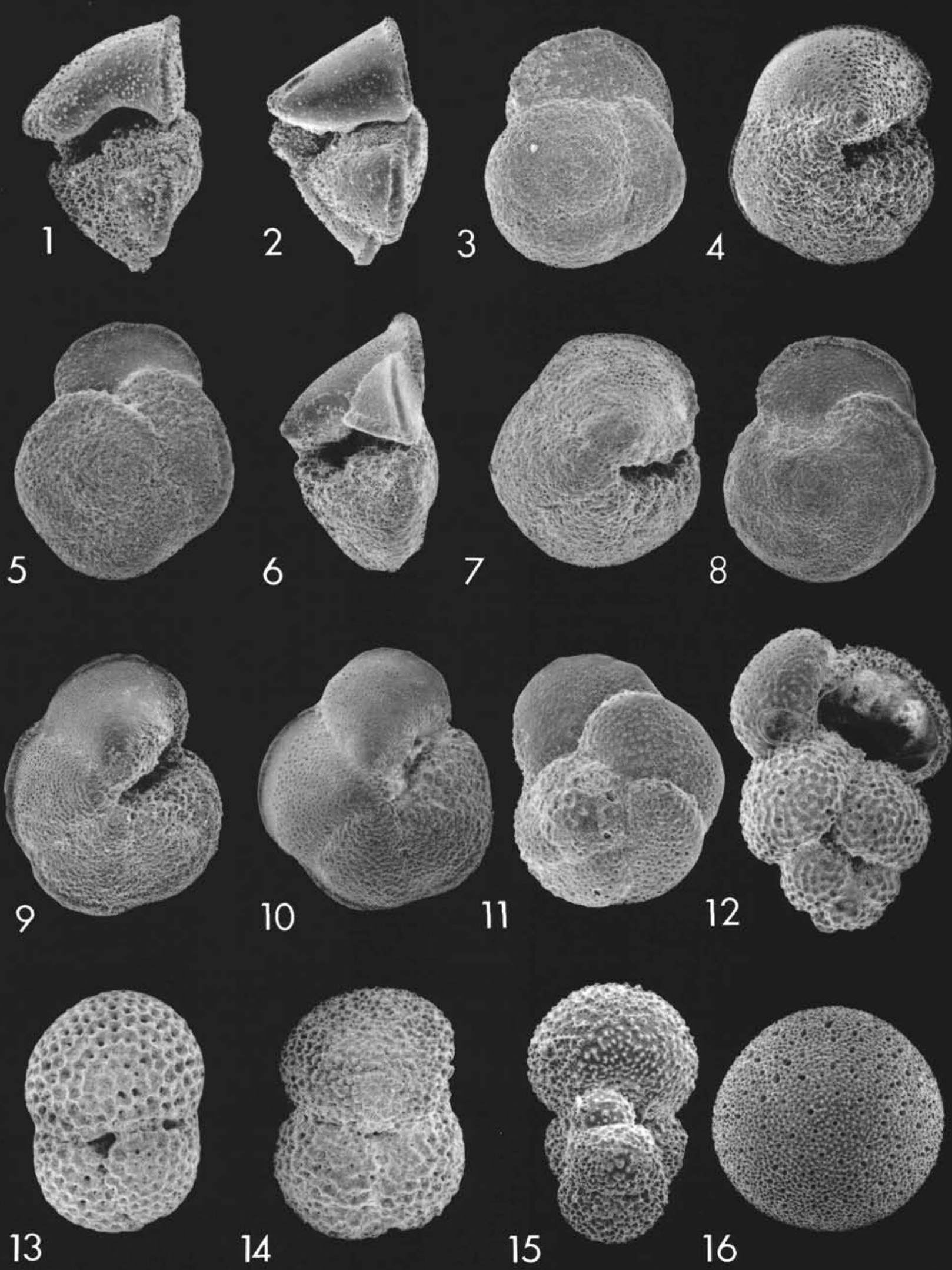


\section{PLATE 8}

Figure 1 Hastigerina aequilateralis Brady; Sample 284-1-1, $25 \mathrm{~cm}$; umbilical view; $\times 111$.

Figure 2 Globigerinoides sacculifer (Brady); Sample 284-9-5, $40 \mathrm{~cm}$; umbilical view; $\times 134$.

Figures 3, 4 Globigerinoides ruber (d'Orbigny); Sample 284-1-5, $40 \mathrm{~cm}$.

3. Umbilical view; $\times 135$.

4. Umbilical view; $\times 129$.

Figure 5 Globigerinoides obliquus Bolli; Sample 284-9-5, 40 $\mathrm{cm}$; side view; $\times 148$.

Figure 6 Globigerinoides tenellus Parker; Sample 284-3-2, 40 $\mathrm{cm}$; umbilical view; $\times 225$.

Figure $7 \quad$ Sphaeroidinella seminulina (Schwager); Sample 284A-3-6, $80 \mathrm{~cm}$; side view; $\times 101$.

Figure 8 Globorotalia miozea conoidea Walters; Sample 284-18-6, $40 \mathrm{~cm}$; side view; $\times 104$.

Figure 9 Globorotalia miozea conoidea Walters; Sample 284-22-2, $40 \mathrm{~cm}$; side view; $\times 91$.

Figure $10 \quad$ Globorotalia miozea conoidea Walters; Sample 284-18-6, $40 \mathrm{~cm}$; spiral view; $\times 84$.

Figures 11-13 Globigerinita glutinata (Egger); Sample 284-6-1, 40 $\mathrm{cm}$.

11. Umbilical view; $\times 200$.

12. Umbilical view; $\times 199$.

13. Umbilical view; $\times 211$.

Figure 14 Globigerinita uvula (Ehrenberg); Sample 284-14-1, $40 \mathrm{~cm}$; side view; $\times 246$. 

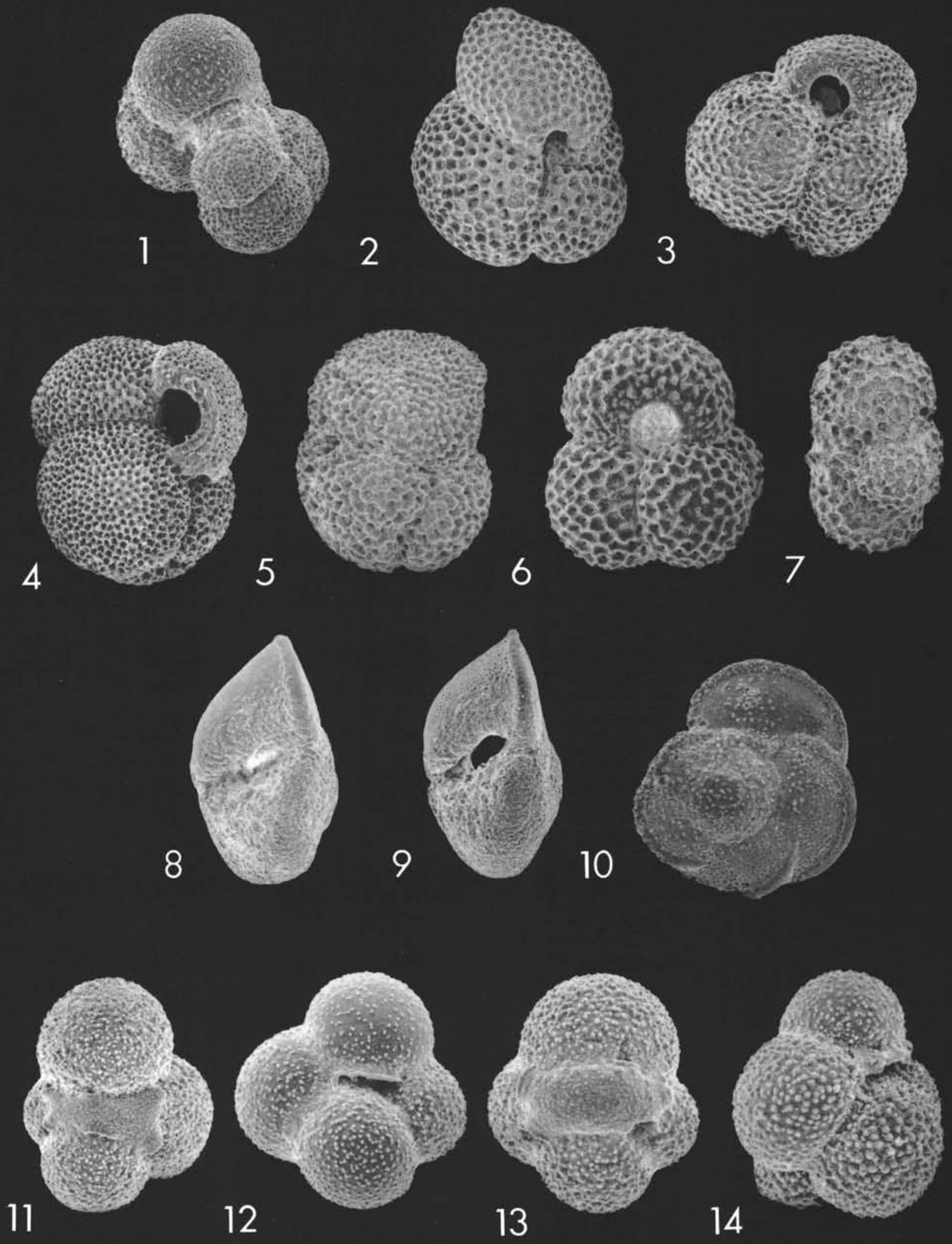